\title{
Hygroscopic properties of atmospheric aerosol particles over the Eastern Mediterranean: implications for regional direct radiative forcing under clean and polluted conditions
}

\author{
M. Stock ${ }^{1}$, Y. F. Cheng ${ }^{1, *}$, W. Birmili ${ }^{1}$, A. Massling ${ }^{1, * *}$, B. Wehner ${ }^{1}$, T. Müller ${ }^{1}$, S. Leinert ${ }^{2}$, N. Kalivitis ${ }^{3}$, \\ N. Mihalopoulos ${ }^{3}$, and A. Wiedensohler ${ }^{1}$ \\ ${ }^{1}$ Leibniz Institute for Tropospheric Research, Leipzig, Germany \\ ${ }^{2}$ Environmental Protection Agency, Dublin 14, Ireland \\ ${ }^{3}$ Environmental Chemical Processes Laboratory, University of Crete, Heraklion, Greece \\ * now at: Center of Global and Regional Environment Research, University of Iowa, Iowa City, USA \\ *** now at: National Environmental Research Institute, Aarhus University, Roskilde, Denmark
}

Received: 14 October 2010 - Published in Atmos. Chem. Phys. Discuss.: 3 November 2010

Revised: 19 April 2011 - Accepted: 19 April 2011 - Published: 9 May 2011

\begin{abstract}
This work examines the effect of direct radiative forcing of aerosols in the eastern Mediterranean troposphere as a function of air mass composition, particle size distribution and hygroscopicity, and relative humidity (RH). During intensive field measurements on the island of Crete, Greece, the hygroscopic properties of atmospheric particles were determined using a Hygroscopicity Tandem Differential Mobility Analyzer (H-TDMA) and a Hygroscopicity Differential Mobility Analyzer-Aerodynamic Particle Sizer (H-DMA-APS). Similar to former studies, the H-TDMA identified three hygroscopic sub-fractions of particles in the sub- $\mu \mathrm{m}$ range: a more hygroscopic group, a less hygroscopic group and a nearly hydrophobic particle group. The average hygroscopic particle growth factors at $90 \%$ RH were a significant function of particle mobility diameter $\left(D_{p}\right): 1.42( \pm 0.05)$ at $30 \mathrm{~nm}$ compared to $1.63( \pm 0.07)$ at $250 \mathrm{~nm}$. The H-DMA-APS identified up to three hygroscopic sub-fractions at mobility diameters of 1.0 and $1.2 \mu \mathrm{m}$. The data recorded between 12 August and 20 October 2005 were classified into four distinct synoptic-scale air mass types distinguishing between different regions of origin (western Mediterranean vs. the Aegean Sea) as well as the degree of continental pollution (marine vs. continentally influenced). The hygroscopic properties of particles with diameter $D_{p} \geq 150 \mathrm{~nm}$ showed the most pronounced dependency on air mass origin, with growth factors in marine air masses
\end{abstract}

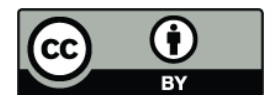

Correspondence to: W. Birmili (birmili@tropos.de) exceeding those in continentally influenced air masses. Particle size distributions and hygroscopic growth factors were used to calculate aerosol light scattering coefficients at ambient RH using a Mie model. A main result was the pronounced enhancement of particle scattering over the eastern Mediterranean due to hygroscopic growth, both in the marine and continentally influenced air masses. When $\mathrm{RH}$ reached its summer daytime values around $70-80 \%$, up to $50-70 \%$ of the calculated visibility reduction was due to the hygroscopic growth of the particles by water compared to the effect of the dry particles alone. The estimated aerosol direct radiative forcings for both, marine and continentally influenced air masses were negative indicating a net cooling of the atmosphere due to the aerosol. The radiative forcing $\Delta F_{\mathrm{r}}$ was nevertheless governed by the total aerosol concentration most of the time: $\Delta F_{\mathrm{r}}$ was typically more negative for continentally influenced aerosols (ca. $-4 \mathrm{~W} \mathrm{~m}^{-2}$ ) compared to rather clean marine aerosols (ca. $-1.5 \mathrm{~W} \mathrm{~m}^{-2}$ ). When $\mathrm{RH}$ occasionally reached $90 \%$ in marine air masses, $\Delta F_{\mathrm{r}}$ even reached values down to $-7 \mathrm{~W} \mathrm{~m}^{-2}$. Our results emphasize, on the basis of explicit particle hygroscopicity measurements, the relevance of ambient RH for the radiative forcing of regional atmospheres.

\section{Introduction}

In the accretive discussion on global climate change, atmospheric particles (aerosols) have been identified as a key uncertainty with respect to the global radiative balance (IPCC,

Published by Copernicus Publications on behalf of the European Geosciences Union. 
2007). Particles influence climate directly by scattering and absorbing solar radiation (Haywood and Boucher, 2000) and indirectly through their ability to act as cloud condensation nuclei (CCN), (Twomey, 1977; Ogren and Charlson, 1992). A sufficient knowledge of the microphysical properties of aerosol particles as well as the spatial distribution is a key to evaluate their effect on global climate. Experimental data, in particular, are necessary as input and validation parameters for global climate models, which assess the role of aerosols in future scenarios of global warming or cooling (Grant et al., 1999).

The hygroscopic growth behaviour of aerosol particles is one of the important parameters controlling the direct and indirect climate effects. Atmospheric particles can absorb water at relative humidities well below $100 \%$ depending on their chemical composition. Due to water uptake aerosol particles change their size and their optical properties (Tang, 1996). The major portion of hygroscopic particle growth is usually related to inorganic species, such as ammonium nitrate, ammonium sulphate, and sodium chloride, whose hygroscopic growth behaviour is known relatively accurately (Tang and Munkelwitz, 1994; Brechtel and Kreidenweis, 2000). In contrast, the understanding of the growth behaviour of particulate organic matter (POM) has been more patchy, due to the myriad of individual species involved (Saxena and Hildemann, 1996). This lack of understanding has also hampered a better understanding of the role of POM on climate (Kanakidou et al., 2005). Considerable improvements have, however, been made in the characterisation of individual organic species as well as lump fractions with regard to their physico-chemical properties, based on both, laboratory and field measurements (Fuzzi et al., 2006).

A quantitative discussion of the consequences of particle hygroscopicity in the eastern Mediterranean region has been scarce (Van Dingenen et al., 2005; Sciare et al., 2003; Bougiatioti et al., 2009). Especially information about hygroscopic behavior of the Mediterranean aerosol has not been available until very recently (Pikridas et al., 2010). The relevance of the eastern Mediterranean troposphere derives from the high amounts of humidity present in the atmosphere - leading to enhanced hygroscopic particle growth) and the region being located on the crossroads of European anthropogenic pollution as well as African dust emission that immerse with the regional marine aerosol (Lelieveld et al., 2002; Pikridas et al., 2010).

This paper reports novel field observations of the hygroscopic properties of fine and coarse aerosol particles representative of the East Mediterranean region. Different instrumental techniques including a H-TDMA instrument and a H-DMA-APS instrument were deployed at the Finokalia research station on Crete (Greece) to characterize the hygroscopic properties of the eastern Mediterranean aerosol fine and coarse particle size range. We further combine these data with simultaneous in-situ aerosol optical observations as well as particle number size distributions presented in an

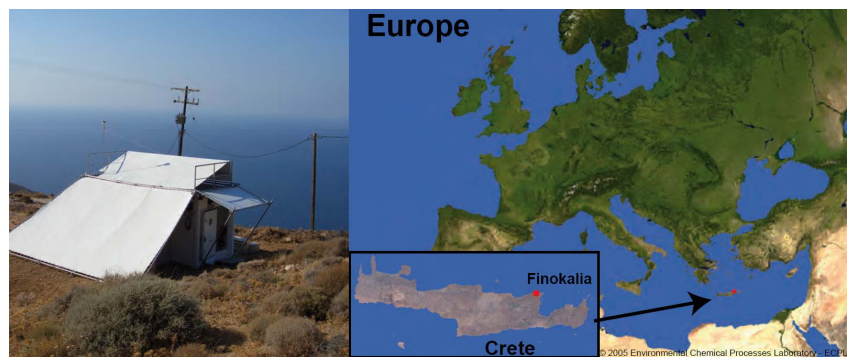

Fig. 1. Atmospheric aerosol measurements during ARIADNE: Container laboratory (left), and location of the Finokalia research site on Crete, in the eastern Mediterranean (right).

earlier paper (Kalivitis et al., 2008) to examine the role of air mass character, either marine or continentally influenced. As an application, the measured size-segregated particle hygroscopic growth factors were used in an optical radiation transfer model to investigate the influence of the prevailing ambient RH on the ambient particle scattering coefficients and therewith on the resulting aerosol direct radiative forcing.

\section{Experimental}

\subsection{Field experiment}

The field experiment ARIADNE (Aerosol Physical and Chemical Identification on Crete) was conducted during ten weeks between 12 August and 20 October 2005 at the research station Finokalia $\left(35.3^{\circ} \mathrm{N}, 25.7^{\circ} \mathrm{E}\right)$ on Crete, Greece. Fig. 1 shows that the site's location on the northern coast of Crete ensures that air is advected from the sea most of the time, thus limiting disturbances by land-based sources. The nearest urban centre is Heraklion with 150000 inhabitants located $70 \mathrm{~km}$ west of Finokalia. The station is located at the top of a hilly elevation ( $250 \mathrm{~m}$ above sea level) facing the sea within the northerly wind sector between $270^{\circ}$ to $90^{\circ}$. The nearest village with 10 inhabitants is at a distance of $3 \mathrm{~km}$ to the south of the station. No human activities can be found at a distance shorter than $15 \mathrm{~km}$ within the above mentioned sector. A comprehensive description of the Finokalia station and the suite of atmospheric measurements conducted there are given in Mihalopoulos et al. (1997) and on the station's website (http://finokalia.chemistry.uoc.gr).

In-situ aerosol measurements were carried out from inside a container laboratory, located at a distance of $200 \mathrm{~m}$ from the main building of the University of Crete's research station. Ambient air was sampled at a total flow rate of $16.71 \mathrm{~min}^{-1}$ through a $\mathrm{PM}_{10}$ inlet placed $6 \mathrm{~m}$ above the ground. When entering the container, the sample aerosol was conditioned to a low-humidity state. Both Nafion ${ }^{\mathrm{TM}}$ membrane diffusion dryers (model MD-110-12-F, Perma Pure LLC, Toms River, NJ, USA) and custom-made silica gel 
diffusion dryers were deployed to limit the relative humidity $(\mathrm{RH})$ in the sampling lines below $30 \%$. The desiccation served two purposes: First, condensation of moisture was avoided when the sample aerosol enters the air-conditioned laboratory container. Second, aerosol samples were prepared within a defined range of $\mathrm{RH}$, which facilitates intercomparisons with other measurements (e.g., Bergin et al., 1997; Carrico et al., 2003).

\subsection{Particle number size distributions (DMPS-APS)}

A flow-controlled closed-loop Differential Mobility Particle Sizer (DMPS; Birmili et al., 1999) was used to measure particle number size distributions in the mobility diameter $\left(D_{p}\right)$ range $18-800 \mathrm{~nm}$. The sheath air in the DMPS was circulated in a closed loop, and maintained at an RH between 10 and $30 \%$ using a silica gel dryer. The time resolution of the DMPS was 10 min. An Aerodynamic Particle Sizer (APS; TSI Inc., St. Paul, USA, Model 3321) was operated measuring the number size distributions of particles with aerodynamic diameters $D_{\text {ae }}$ between 0.8 and $10 \mu \mathrm{m}$. The aerodynamic diameters $D_{\text {ae }}$ were converted to mobility diameters $D_{p}$ using an effective dry particle density of $1.7 \mathrm{~g} \mathrm{~cm}^{-3}$. This particluar value is close to the bulk densities of ammonium sulphate and nitrate, the main constituents of accumulation mode particles (cf. Fig. 2), and reconciled the DMPS and APS distributions in their overlap region very well. We are aware that this density assumption is likely to be less accurate for the coarse mode $\left(D_{p}>1 \mu \mathrm{m}\right)$, where sodium chloride is the main constituent.

The DMPS and APS were corrected for diffusional and gravitational losses occurring in the sampling tubes using the analytical formulae for laminar pipe flows (Willeke and Baron, 1993). DMPS and APS distributions were subsequently combined into a continuous size distribution across the full diameter range. The absolute measurement uncertainties with respect to particle counting and sizing in the DMPS are estimated to be $10 \%$ and $5 \%$, respectively, based on laboratory calibrations. For the APS, these values were both estimated to be $10 \%$ (Wex et al., 2002).

\subsection{Fine particle hygroscopicity (H-TDMA)}

The hygroscopic properties of fine particles were analyzed using a Hygroscopic Tandem DMA (H-TDMA). For the basic concept and details of the instrument see Massling et al. (2003, 2005).

Briefly, the H-TDMA consists of two sequential Differential Mobility Analyzers (DMA, Hauke medium) coupled with two Condensation Particle Counters (CPC, TSI 3010) as counting devices. The first DMA selected a monodosperse particle size fraction from the polydisperse ambient aerosol at dry conditions. Half of the aerosol sample flow leaving the DMA was conducted to the first CPC, where the particle concentration of the monodisperse aerosol was determined,

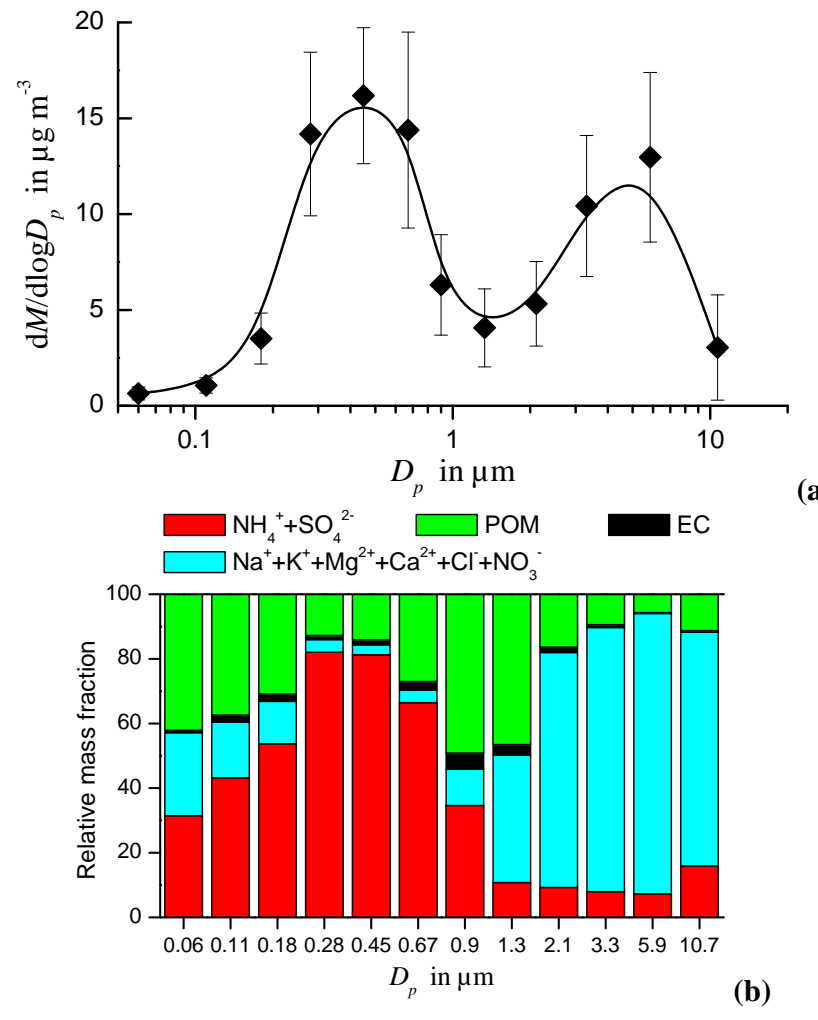

Fig. 2. Mass size distribution and chemical composition of aerosol particles during ARIADNE: (a) average mass size distribution with one standard deviation, (b) chemical composition, classified into four groups including ammonium sulfate $\left(\mathrm{NH}_{4}^{+}+\mathrm{SO}_{4}^{2-}\right)$, fresh and processed sea-salt $\left(\mathrm{Na}^{+}+\mathrm{K}^{+}+\mathrm{Mg}^{2+}+\mathrm{Ca}^{2+}+\mathrm{Cl}^{-}+\mathrm{NO}_{3}^{-}\right)$, elemental carbon (EC) and particulate organic matter (POM).

whereas the other half was humidified to $90 \%$ RH before entering the second DMA. The second DMA scanned an interval of the humidified particle size distribution and worked in combination with the second CPC as a size spectrometer to determine the hygroscopic growth factors and number fractions of individual hygroscopic growth groups that occurred in the spectra.

The H-TDMA system was operated at $90 \% \mathrm{RH}$ and at initial dry diameters of $D_{p}=30,50,80,150,250$ and $350 \mathrm{~nm}$. A complete cycle of six spectra took approximately one hour including a calibration scan with sodium chloride particles at $D_{p}=100 \mathrm{~nm}$. The absolute measurement uncertainty of the RH sensor (Vaisala Oyj, Helsinki, Finland) is, according to our experience, $2 \%$ for $\mathrm{RH}>90 \%$. This uncertainty can propagate into an error in hygroscopic growth factor of about $7 \%$.

Quality control involved a verification of the H-TDMA's instrumental parameters. Generally, fluctuations within $\pm 1 \%$ in $\mathrm{RH}$ and $\pm 1 \%$ in the DMA flow rates during one scan were accepted. Scans with unstable concentrations in the first CPC or incorrect measurements by the second CPC were excluded from further data analysis. 


\subsection{Coarse particle hygroscopicity (H-DMA-APS)}

The hygroscopic properties of coarse particles were analyzed using a Hygroscopicity Differential Mobility AnalyserAerodynamic Particle Sizer system (H-DMA-APS). Details of this instrument have been reported in Leinert and Wiedensohler (2008).

Briefly, the H-DMA-APS consists of a High Aerosol Flow DMA (HAF-DMA) and two additional APS instruments (model 3320, TSI Inc.). The HAF-DMA is a custom-built DMA, which was operated at an aerosol flow of $21 \mathrm{~min}^{-1}$ and a sheath air flow of $201 \mathrm{~min}^{-1}$. Downstream of the HAF-DMA the sample flow was divided into two parts. One part was supplied to the first APS, measuring the particle number size distribution at dry conditions $(\mathrm{RH}<10 \%)$, and the other part was conditioned to a certain, defined RH before being analyzed by the second APS at this RH. Thus, with the first APS the number size distribution downstream of the HAF-DMA in dry state was determined and with the second APS the humidified number size distribution of the monodisperse aerosol at defined conditions was measured. For this reason, the sheath air of the second APS was conditioned to the same RH as the sampled and humidified aerosol. The H-DMA-APS system was used to measure the hygroscopic growth of particles at dry mobility diameters 1.0 and $1.2 \mu \mathrm{m}^{1}$. One measurement required between 15 and $30 \mathrm{~min}$, depending on the available ambient particle concentration. Every four hours a calibration scan was carried out using polystyrene particles $\left(D_{p}=1.05 \mu \mathrm{m}\right)$ to verify drifts related to particle sizing.

The quality check of the H-DMA-APS included also an inspection of the relative humidity and the determination of the Poisson error of the APS counts. The presented H-DMA-APS results are averaged over $12 \mathrm{~h}$ in order to achieve statistically robust results. The flow rates and the relative humidities fluctuated during one scan in a range of \pm 2 $3 \%$. This higher fluctuation in comparison to the H-TDMA is caused by the longer sampling time for this instrument. An uncertainty of $2 \%$ in RH leads to a $6-10 \%$ theoretical uncertainty in all determined growth factors.

\subsection{Aerosol optical scattering and absorption}

The total and backscattering coefficients ( $\sigma_{\mathrm{sp}, \text { neph }}$ and $\sigma_{\text {bsp,neph }}$, respectively) were measured at dry conditions with a three-wavelength, and total/backscatter nephelometer (model 3563, TSI Inc., Shoreview, MN, USA) at the wavelengths of 450, 550 and $700 \mathrm{~nm}$. For the basic design and applications of the instrument, see Heintzenberg and Charlson (1996). Calibrations were carried out with filtered particlefree air as the low span gas and $\mathrm{CO}_{2}$ as the high span gas

\footnotetext{
${ }^{1}$ The nominal setting of the instrument was $1.0 \mu \mathrm{m}$. The diameter of $1.2 \mu \mathrm{m}$ was additionally selected because it stretched the instrument's operation to its upper sizing capability.
}

(Anderson and Ogren, 1998). Zero baseline checks were performed at least once a week.

The truncation error inherent to the nephelometer was corrected by a Mie calculation based on experimental number size distributions. Truncation error factors were applied to each calculated scattering angle to simulate the nephelometer's output (Cheng et al., 2006). The truncation error factors were taken from Anderson et al. (1996) with slight modifications introduced by Heintzenberg et al. (2006). The absolute uncertainty of the measured $\sigma_{\mathrm{sp}, \text { neph }}$ and $\sigma_{\mathrm{bsp}, \text { neph }}$ are estimated to be $7 \%$ (Anderson et al., 1996).

A Multi-Angle Absorption Photometer (MAAP model 5012, Thermo Inc., Waltham, USA) was used to measure the aerosol light absorption coefficient $\left(\sigma_{\mathrm{ap}, \mathrm{MAAP}}\right)$ at a wavelength of $637 \mathrm{~nm}^{2}$ under dry conditions. The MAAP determines aerosol light absorption from the simultaneous measurements of radiation passing through and scattered back from particles accumulating on a filter tape. It operates at three detection angles to resolve the influence of lightscattering aerosol components on the angular distribution of the back scattered radiation (Petzold and Schönlinner, 2004).

The flow rate was calibrated once per week using a bubble flow meter. Using a specific attenuation cross section of $6.6 \mathrm{~m}^{2} \mathrm{~g}^{-1}$ the MAAP converts the light absorption signal into a mass concentration of black carbon (soot). The absolute measurement uncertainty of the MAAP was determined to be $12 \%$ (Petzold and Schönlinner, 2004) while laboratory intercomparisons of multiple MAAP instruments suggested a unit-to-unit variability below 3\% (Müller et al., 2011).

\subsection{Chemical composition}

Aerosol samples for subsequent chemical analysis were collected using a Small Deposit Area Low Volume Impactor (SDI; Maenhaut et al., 1996). The upper cut-off size of the device was $10 \mu \mathrm{m}$, with 12 collection stages being provided between 0.041 and $10 \mu \mathrm{m}$. During ARIADNE the average sampling period was $48 \mathrm{~h}$ at a flow rate of $111 \mathrm{~min}^{-1}$. The filters were covered by aluminium foil, sealed in polyethylene bags and stored in a refrigerator at $4{ }^{\circ} \mathrm{C}$ prior to analysis. Chemical analysis yielded inorganic ions as well as elemental carbon (EC) and particulate organic matter (POM). For technical details of the analytical procedures see Teinilä et al. (2000).

\footnotetext{
${ }^{2}$ The manufacturer specifies a wavelength of $670 \mathrm{~nm}$. Experimental verification of the wavelength in the laboratory, hovewer, yielded a value of $637 \mathrm{~nm}$ (Müller et al., 2011).
} 


\section{Data processing}

\subsection{Hygroscopic growth factors and number fractions}

\subsubsection{H-TDMA data}

Gaussian distributions were fitted to the particle number size distribution recorded by the H-TDMA downstream of the humidification step. On the basis of their modal mean diameters, wet particle growth factors $g f_{\text {ve }}$ were calculated for submicrometer sizes $(30-350 \mathrm{~nm})$ from the ratio between wet and dry particle diameters:

$g f_{\mathrm{ve}}=\frac{D_{p, \text { wet }(\mathrm{ve})}}{D_{p, \text { dry }(\mathrm{ve})}}$

Using the particle number integrals, number fractions $n f$ for each of the three hygroscopicity modes were determined, with the sum of these number fractions equalling one.

Sodium chloride calibration scans performed at $90 \% \mathrm{RH}$ were used to retrieve the real RH inside the second (humidified) DMA. The two-component solubility model introduced below in Sect. 3.2.1 was used to adjust the hygroscopic growth factors to a standard RH of $90 \%$, ensuring a homogeneous data set.

In a second step, the information on the three hygroscopicity modes in the sub- $\mu \mathrm{m}$ range was merged into an "overall" hygroscopic growth factor $g f_{\mathrm{v}-\text { mean }}$ representative for the entire particle population at a given $D_{p \text {,dry. This was }}$ achieved by a volume-weighted averaging of the growth factors using the modal number fractions $n f$ :

$g f_{\mathrm{v}-\text { mean }}=\sqrt[3]{\sum_{i=1}^{3} g f_{i, \mathrm{ve}}^{3} \cdot n f_{i}}$.

\subsubsection{H-DMA-APS data}

The characteristics of the measured humidified size distributions differed between the H-TDMA and the H-DMA-APS. The dry size distribution measured with the first APS of the H-DMA-APS showed a bimodal and sometimes a trimodal behavior. The reason was the combination of the different measurement principles of DMA and APS. Larger particles with multiple charges were observed as a small mode right of the main peak in the particle number size distribution measured with the dry APS. This mode was not used for the determination of hygroscopic growth ${ }^{3}$. Small hydrophobic particles with higher shape factors and the same electrical mobility as the particles of the main peak appeared in the

\footnotetext{
${ }^{3}$ The peak areas of such potentially doubly charged particles were significantly lower than those of singly charged particles, ca. $20 \%$ of the area of the main peak. This is consistent with larger, multiply charged particles being less abundant than smaller, singly charged ones, so that their overall effect on the determined growth factors was minor.
}

dry particle number size distribution left to the main peak. The same group of hydrophobic particles was found in the wet particle number size distributions. The parameters of the left mode and the main mode were used to determine the aerodynamic growth factors and their corresponding number fractions of different hygroscopic growth groups measured with the H-DMA-APS system. The determination of aerodynamic growth factors and number fractions was performed in the same fashion as for the H-TDMA above.

\subsection{Hygroscopic growth model}

\subsubsection{Two-component solubility model}

A simplistic two-component solubility model was employed to predict the hygroscopic growth factors of the Finokalia aerosol for a wider range of ambient relative humidities (30$95 \%$ ). This allows to generalise the hygroscopicity measurements, which were always accomplished at $90 \% \mathrm{RH}$ by the H-TDMA and at $85 \%$ RH by the H-DMA-APS.

In this work we pursue a simplistic approach. The features of the solubility model are:

1. All particles are homogeneous and internally mixed.

2. Each particle contains an insoluble core (soot or dust) as well as a soluble shell.

3. In the sub- $\mu \mathrm{m}$ range, ammonium sulphate is taken as the main soluble specie. H-TDMA data are used to "calibrate" the model.

4. In the super- $\mu \mathrm{m}$ range, sodium chloride is taken as the main soluble specie. H-DMA-APS data and chemical particle composition are used to "calibrate" the model.

The motivation for ammonium sulphate and sodium chloride as the main soluble fraction is that both species have very high hygroscopic growth factors and are dominant in the fine and coarse particle mass modes, respectively (Fig. 2). The present model apparently neglects the effects of particulate organic matter (POM). We will argue below that neglection of POM as a separate soluble fraction will have only limited effects on the radiation transfer calculations accomplished in this paper.

A key operational key parameter of the hygroscopic growth model is a soluble volume fraction $\varepsilon$, which is derived from the following equation Swietlicki et al. (1999):

$\varepsilon=\frac{g f_{\text {measured }}(\mathrm{RH})^{3}-1}{g f_{\text {soluble }}(\mathrm{RH})^{3}-1}$.

$\varepsilon$ changes along with the measured hygroscopic growth factors and is therefore a time-dependent "image" of the hygroscopicity measurement. Here, $g f_{\text {soluble }}$ is the hygroscopic growth factor of a hypothetical particle consisting only of soluble material and having the same wet diameter as the measured ambient particle. 
Calculations with Eq. (3) were performed for all three hygroscopicity groups identified in the H-TDMA and H-DMAAPS spectra. The total soluble volume fraction $\varepsilon_{\text {tot }}$ was subsequently determined by weighing their individual soluble fractions with their corresponding number fractions:

$\varepsilon_{\mathrm{tot}}=\sum_{i=1}^{3} n f_{i} \cdot \varepsilon_{i}$

An average hygroscopic growth factor (i.e. representative for an entire particle population at $D_{p \text {,dry }}$ ) can then be calculated for any RH by dissolving Eq. (3) after $g f_{\text {measured, }}$, and inserting $g f_{\text {soluble }}$ for the given relative humidity. In the calculations we always assume a particle state above the deliquescence point.

\subsubsection{Speciation of the soluble fraction}

An important question in each hygroscopic growth model is the identification and description of the soluble fraction. It is obvious from the body of previous field and laboratory studies that inorganic ions cause the major fraction of water uptake. In our simplistic approach in Sect. 3.2.1 we associate $g f_{\text {soluble }}$ in Eq. (3) with ammonium sulphate in the sub- $\mu \mathrm{m}$ range and sodium chloride in the super- $\mu \mathrm{m}$ range. In both branches of the model, the laboratory-based hygroscopic growth factors of Tang and Munkelwitz (1994) are used as $g f_{\text {soluble }}$ for each given particle diameter. A main motivation for the choice of these species is chemical particle composition (Fig. 2).

We are, however, aware of limitations of our model, particularly because particulate organic matter (POM) is not treated separately. As evident from Fig. 2, POM is visibly present in the Finokalia aerosol, with mass fractions approaching $50 \%$ especially at diameters around $1 \mu \mathrm{m}$ and below $200 \mathrm{~nm}$. Indeed, a significant part of POM is expected to be soluble (Fuzzi et al., 2006). Due to the diverse observations related to POM-based hygroscopic behaviour, however, it is not straightforward to opt for a generally valid growth mechanism. Laboratory work by Varutbangkul et al. (2006), for instance, determined growth factors of atmospherically relevant secondary organic aerosol (SOA) species across a relatively narrow range of 1.1-1.2 at $90 \% \mathrm{RH}$. Massoli et al. (2010) identified, again in the laboratory, a strong and positive relationship between the oxidation state of SOA and their hygroscopic growth factors across a range $1.0-1.4$ at $90 \%$ RH. For marine and continental environmental aerosols, Gysel et al. (2007) obtained an adequate agreement between measured and simulated hygroscopic growth factors when assuming an organic ensemble growth factor around 1.2 at $90 \% \mathrm{RH}$.

A further important question is whether POM will mix ideally with the inorganic species, or alternatively partition to the insoluble core, or even a less hygroscopic shell. To make things even more complicated, the presence of
POM can influence the relative partitioning of semi-volatile compounds like nitrate into the particulate and gas phases (Anasari and Pandis, 2000). According to several laboratory studies, however, the ZSR mixing relationship might indeed be a valid assumption for a range of atmospherically relevant organic/inorganic mixtures (Svenningson et al., 2005; Meyer et al., 2009). It also seems that the presence of POM in an internally mixed aerosol prevents the usual recrystallisation of inorganic compounds.

An essential limitation of the ARIADNE study remains that no detailed organic speciation could be performed. Follow-up measurements to ARIADNE showed that the Finokalia fine mode organic aerosol is overwhelmingly soluble: $75 \%$ of POM was found to be water-soluble (Hildebrand et al., 2010). Nevertheless, solubility does not necessarily imply a strong hygroscopicity: EUCAARI measurements at Finokalia suggested the water uptake of the by the aged organic aerosol to be relatively modest, and to account for a few per cent of the total water uptake only (Bougiatioti et al., 2009; Engelhart et al., 2011). In conclusion, the water uptake by organics is expected to make up a minor fraction of the total water uptake in Finokalia aerosol.

We also point out that the solubility model is calibrated to the experimental H-TDMA data, i.e. information on all soluble species, wether inorganic or organic, is carried into the calculated soluble volume fraction $\varepsilon$. The model preserves the experimental data, so that predictions for RH other than $90 \%$ are accurate as the POM mixes well with the inorganic fraction, and the real POM fraction accumulates water along with increasing RH in a similar fashion as the inorganic fraction. As a result of the arguments given, we believe that the neglection of POM as an separate soluble fraction will have only a limited effect on the radiation transfer calculations conducted in Sect. 5.

\subsubsection{Parameterisation of particle hygroscopicity}

To describe a size-resolved particle hygroscopic growth and subsequently particle number size distributions at ambient $\mathrm{RH}$, the following parameterisation was developed:

For the fine particle mode $\left(D_{p} \leq 700 \mathrm{~nm}\right)$, Eq. (3) was applied to derive $g f$ at the experimental ambient $\mathrm{RH}$, which occurred across the range of 30-95\% during ARIADNE. Input parameters are the growth factors of ammonium sulfate (Tang and Munkelwitz, 1994) as $g f_{\text {soluble, and the "soluble }}$ fraction" $\varepsilon$ that was determined before for any point in time from the H-TDMA measurements at the fixed RH of $90 \%$ using the same equation.

For the coarse particle mode $\left(D_{p} \geq 1.3 \mu \mathrm{m}\right)$ a hygroscopic growth model based on experimental chemical composition was applied. We disregarded the H-DMA-APS data because we thought their information at 1.0 and $1.2 \mu \mathrm{m}$ is not representative enough to describe the entire coarse mode (cf. Fig. 2). Chemical composition of super- $\mu$ m particles was dominated by fresh and processed sea-salt particles 


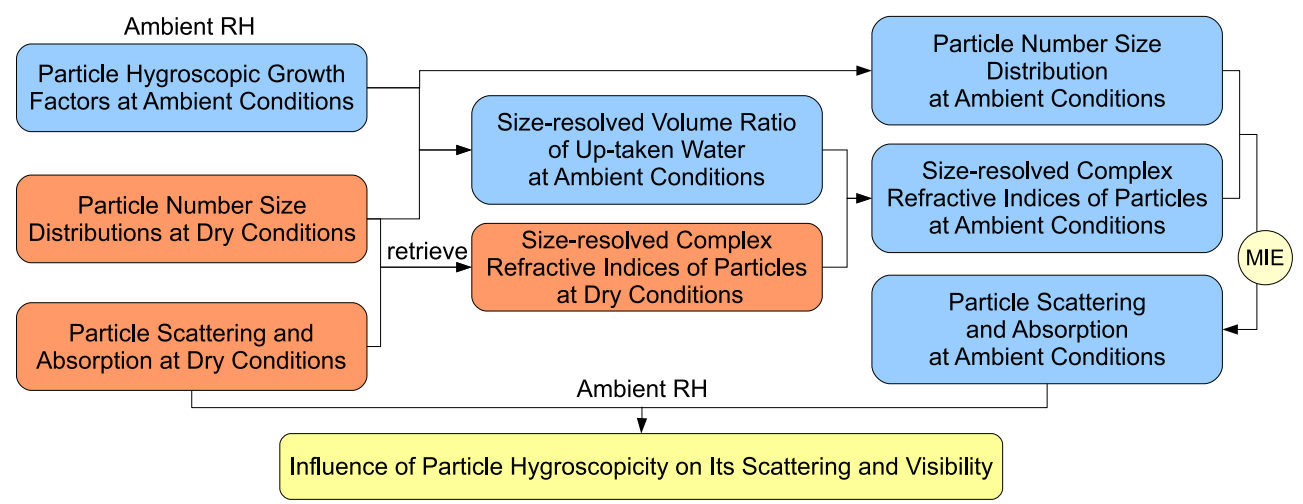

Fig. 3. Simulating aerosol properties at ambient conditions using the optical model.

containing sodium chloride and sodium nitrate (Fig. 2). Accordingly, a three-component model was devised combining an insoluble fraction (supposedly dust) with two soluble fractions of sodium nitrate and sodium chloride, respectively. The growth of the soluble species was again based on experimental data (Tang and Munkelwitz, 1994), with both solutes acting like in an ideally mixed solution (Zdanovskii, 1948; Stokes and Robinson, 1966). The described model was used to calculate the $g f\left(D_{p}, \mathrm{RH}\right)$ of particles in the mobility diameter range $1.3-10 \mu \mathrm{m}$ at prevailing ambient $\mathrm{RH}$.

In the intermediate $D_{p}$ range $700-1300 \mathrm{~nm}$, both parameterisations were interpolated to provide a smooth transition between the fine and coarse particle modes. On the basis of these parameterizations of particle hygroscopicity, $g f\left(D_{p}, \mathrm{RH}\right)$ and dry particle number size distributions were used to calculate particle number size distributions at ambient RH (30-95\%, average: $71 \%)$.

\subsection{Optical model and retrieval of refractive index}

To examine the influence of the particle's hygroscopicity on its light scattering and therewith on the local visibility, an optical model was conceived to simulate optical particle properties at ambient RH. The general data processing scheme is outlined in Fig. 3. Particles are assumed to grow as a result of their interaction with water vapour. Particle are further assumed to be spherical, so that the homogeneous spherical Mie code (Bohren and Huffman, 1998) can be applied. Although not verified explicitly, there is at least indirect evidence for a rather spherical shape of the particles at Finokalia: In summer, polluted air masses are associated mainly with northerly winds, i.e. air will travel several hours above the seawater before reaching the station. This usually leads to an enrichment of sea-water components in the aerosol, such as methanesulfonic acid (Bardouki et al., 2000; Kouvarakis et al., 2002). Accumulation of such water-based compounds are supportive in achieving a rather spherical particle shape.
As illustrated in the right-hand part of Fig. 3, particle number size distributions and complex refractive indices at ambient RH were required as input parameters for the optical model. As can also be seen in Fig. 3, the optically derived effective complex refractive index $\left(\tilde{m}_{\text {dry }}\left(n_{r}, n_{i}\right)\right)$ of the aerosol particles at dry conditions was determined by iterative Mie calculations utilizing the simultaneous measurements of particle number size distributions, three-wavelength total/hemispheric-back scattering, and one-wavelength absorption coefficients.

It is worth to note that for compounds such as ammonium sulfate and nitrate, the refractive indices do not vary much in the mid-visible wavelength range from 450 to $700 \mathrm{~nm}$. This assumption has been used in many previous optical simulations (Dalzell and Sarofim, 1969; Hasan and Dzubay, 1983; Sloane, 1983, 1984, 1986; Tang and Munkelwitz, 1994; Redemann et al., 2001; Mallet et al., 2006). Bond and Bergstrom (2006) provided an overview of the wavelength dependency of the black carbon's refractive indices. Dalzell and Sarofim (1969) and Lee and Tien (1981) provided parameters that can be used for wavelength-dependent imaginary refractive indices of black carbon by application of a radiation dispersion model. From 450 to $700 \mathrm{~nm}$, the refractive indices of black carbon can vary from 0.35 to 0.45 . Bergstrom et al. (2002) report a similar variation between wavelengths of 0.4 and $1.0 \mu \mathrm{m}$. These authors explored the theoretical basis of the wavelength variation of the absorption of solar radiation by elemental carbon (or black carbon), and found that for a wavelength independent refractive index the small particle absorption limit simplifies to a variation in relatively good agreement with the data.

When retrieving the refractive index under dry conditions, it was initially assumed that it was independent of particle size (Guyon et al., 2003; Schkolnik et al., 2007). The Mie code iteratively determined the $\widetilde{m}_{\text {dry }}$ for a given particle number size distribution by matching the calculated and measured scattering and absorption coefficients $\left(\sigma_{j}^{c}\right.$ and $\sigma_{j}^{e}$, respectively, and $j=1, \ldots, 7$ referring to the seven measured optical parameters), as described by Eq. (5). Here, $n_{r}$ and 
$n_{i}$ were the real and imaginary parts of $\tilde{m}_{\text {dry }}$, respectively. At each time step, only one refractive index was retrieved. Later, we transform this series of "dry-condition" indices to a set of size-dependent "ambient" refractive indices, since sizedependent hygroscopic growth factors are available from the experiment.

The minimization was achieved by a Newton-Raphson Iterative Method (Press et al., 1992):

$\underset{n_{r}, n_{i}}{\operatorname{Minimize}} \chi^{2}\left(n_{r}, n_{i}\right)=\sum_{j=1}^{7}\left|\frac{\sigma_{j}^{c}-\sigma_{j}^{e}}{\sigma_{j}^{e}}\right|^{2}$.

The partial derivatives of $\chi^{2}\left(n_{r}, n_{i}\right)$ with respect to $n_{r}$ and $n_{i}$ vanished when $\chi^{2}\left(n_{r}, n_{i}\right)$ approached the minimum value. $\Delta n_{r}$ and $\Delta n_{i}$ were given by:

$\left[\begin{array}{l}\Delta n_{r} \\ \Delta n_{i}\end{array}\right]=-\mathbf{J}^{-1}\left[\begin{array}{l}\partial \chi^{2} / \partial n_{r} \\ \partial \chi^{2} / \partial n_{i}\end{array}\right]$

where $\mathbf{J}$ was the Jacobian Matrix (Press et al., 1992).

We chose the distance measure $\sqrt{\left(\Delta n_{r}\right)^{2}+\left(\Delta n_{i}\right)^{2}}$ as a stopping threshold, i.e. the iteration converged if this distance fell below defined threshold of $1.0 \times 10^{-7}$.

A sensitivity study was carried out to test whether a unique solution can be achieved for the current data set. A series of refractive indices was assumed to vary from 1.33 to 1.70 for $n_{r}$ and from 0 to 0.1 for $n_{i}$ with respect to the expected range of refractive indices of atmospheric aerosol particles. Together with the average particle number size distribution measured during ARIADNE, they were used to simulate a series of particle optical properties with the homogeneous spherical Mie model (Cheng et al., 2006). The theoretically calculated optical properties and the averaged particle number size distribution again served as input parameters for the retrieving model.

First, the assumed refractive indices could successfully be retrieved. Second, a rough step-search was utilized with a step of 0.05 for $n_{r}$ and 0.005 for $n_{i}$ within the range of 1.0 to 2.0 and 0 to 0.2 , respectively. Contour plots of the differences between the calculated optical properties and theoretically predicted values showed that there was only one unique solution (trough) in the expected ranges of $n_{r}$ and $n_{i}$. Guyon et al. (2003) also found that the iterative calculations always converged toward a unique solution within the range of refractive indices open to the model, except for very little unusual cases. Thus, the interactive method was capable to provide the desired results for the ARIADNE data set.

A Monte Carlo simulation (Wex et al., 2002; Cheng et al., 2006) was carried out by randomly (and simultaneously) varying all input parameters (scattering, absorption coefficients and particle number size distribution) in the retrieving model to investigate the uncertainties of retrieved $\tilde{m}_{\text {dry }}$ due to the uncertainties in the experiments. The uncertainties of the retrieval were found to be $5 \%$ for $n_{r}$ and $10 \%$ for $n_{i}$, which were consistent with Guyon et al. (2003). However, we admit
Table 1. Air mass definitions, based on the mass fraction of soot (EC) $f_{\text {soot }}$ is in particles $<1 \mu \mathrm{m}$ based on SDI chemical analysis.

\begin{tabular}{lllrc}
\hline & Date & Origin & $f_{\text {soot }}$ & Category \\
\hline A1 & $\begin{array}{l}21.09 .0510: 30- \\
25.09 .0500: 00\end{array}$ & $\begin{array}{l}\text { Western Mediter- } \\
\text { ranean Sea }\end{array}$ & $2.8 \%$ & marine \\
A2 & $\begin{array}{l}27.09 .0518: 00- \\
\text { Black Sea }\end{array}$ & $4.5 \%$ & polluted \\
& $30.09 .0518: 00$ & & \\
A3 & $01.10 .0522: 00-$ & Western Mediter- & $3 \%$ & marine \\
& $04.10 .0510: 00$ & ranean Sea & & \\
A4 & $\begin{array}{l}05.10 .0500: 00- \\
12.10 .0500: 00\end{array}$ & $\begin{array}{l}\text { Black Sea and } \\
\text { South-East Europe }\end{array}$ & $5.1 \%$ & polluted \\
& & & \\
\hline
\end{tabular}

that some uncertainties related to assumptions of the model including the spherical shape, homogeneous mixture as well as the non-size dependent assumptions for the retrieved $\tilde{m}_{\text {dry }}$, could not be considered in the form of a rigorous uncertainty analysis. We felt that the computational treatment of any particle morphology other than a homogeneous mixture is outside the scope of this work.

In the next step, the retrieved refractive index at dry conditions and the particle's hygroscopic growth factors $g f\left(D_{p}, \mathrm{RH}\right)$ were used to calculate the refractive indices of particles at ambient RH (see Fig. 3). At each size bin, the up-taken water volume ratio $\left(R_{\mathrm{w}, \mathrm{V}}\left(D_{p}, \mathrm{RH}\right)\right)$, defined as the volume ratio of up-taken water and the total particle at ambient RH was determined as follows:

$R_{\mathrm{w}, \mathrm{V}}\left(D_{p}, \mathrm{RH}\right)=\left(g f\left(D_{p}, \mathrm{RH}\right)^{3}-1\right) / g f\left(D_{p}, \mathrm{RH}\right)^{3}$.

Together with the retrieved $\widetilde{m}_{\text {dry }}$ at dry conditions, the $R_{\mathrm{w}, \mathrm{V}}\left(D_{p}, \mathrm{RH}\right)$ were used to calculate the complex refractive index $\widetilde{m}\left(D_{p}, \mathrm{RH}\right)$ in each size bin at ambient $\mathrm{RH}$ according to a simple volume mixing rule (Covert et al., 1972). As the refractive index of water we used 1.33-0i.

\section{Particle hygroscopicity results}

\subsection{Air mass observations}

Figure 4 shows the time series of the soot mass concentration, the relative mass fraction of soot, and particle mass concentration of particles $<1 \mu \mathrm{m}$. Among all measured aerosol and gas phase parameters, the mass concentration of soot turned out to be the most favourable indicator for the anthropogenic influence on the air masses sampled during ARIADNE. Four distinct time periods (A1-A4) were defined, representing low (A1, A3) and high (A2, A4) mass concentrations of soot (see Table 1). The four periods coincide with the episodes of low and high total particle mass as well as accumulation mode particle number (see Fig. 4). They are also identical to those defined by Kalivitis et al. (2008), who presented particle number size distributions for the periods A1-A4. 


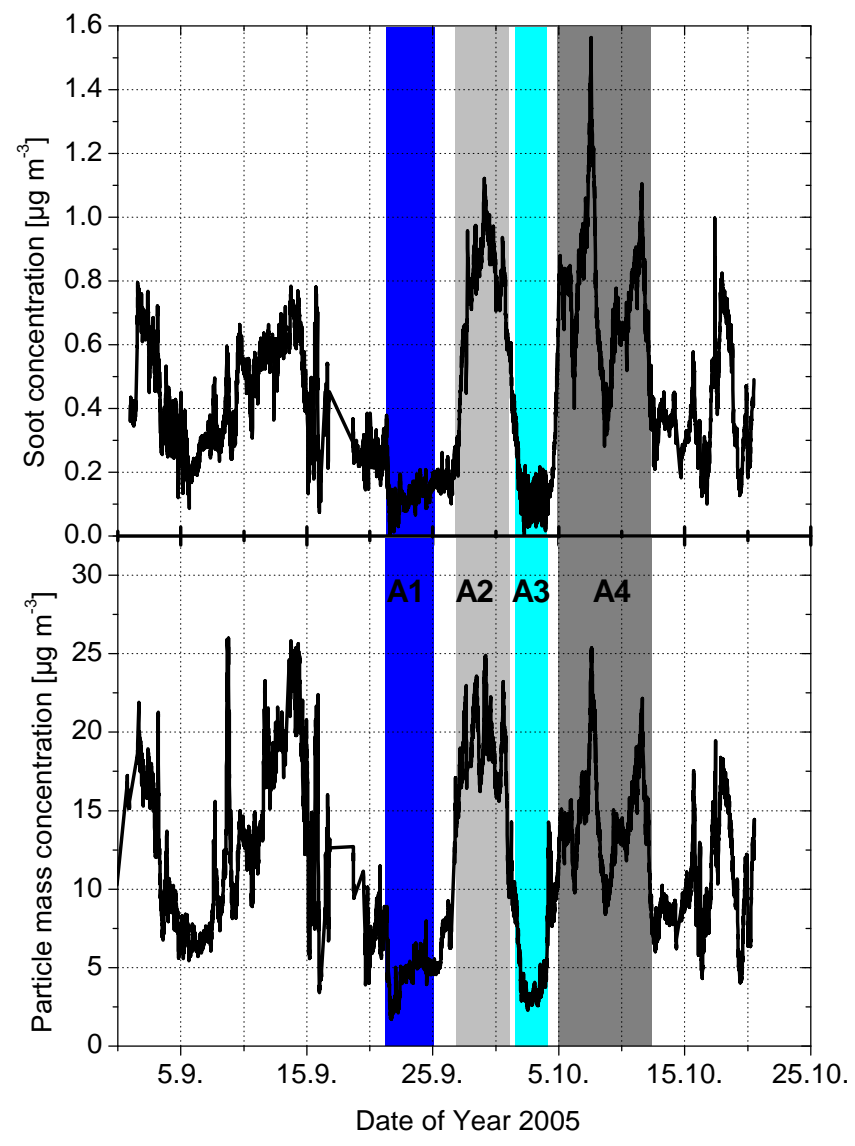

Fig. 4. Soot mass concentration measured by the MAAP instrument, and total particle mass concentration derived from DMPS and APS measurements. A1-A4 indicate four selected time periods representing rather distinct air mass types.

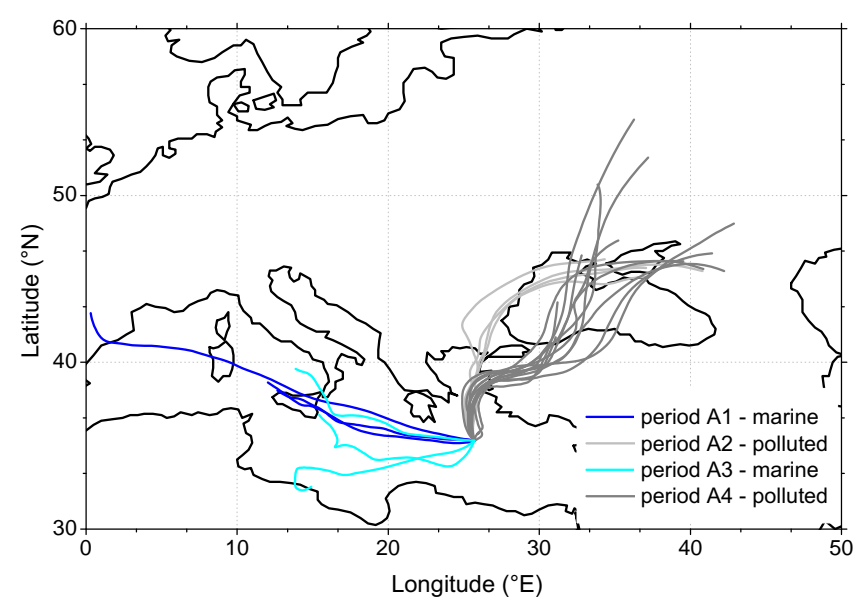

Fig. 5. Backward trajectories (duration $72 \mathrm{~h}$, start height $500 \mathrm{~m}$ ) during ARIADNE, as calculated using the NOAA HYSPLIT model.

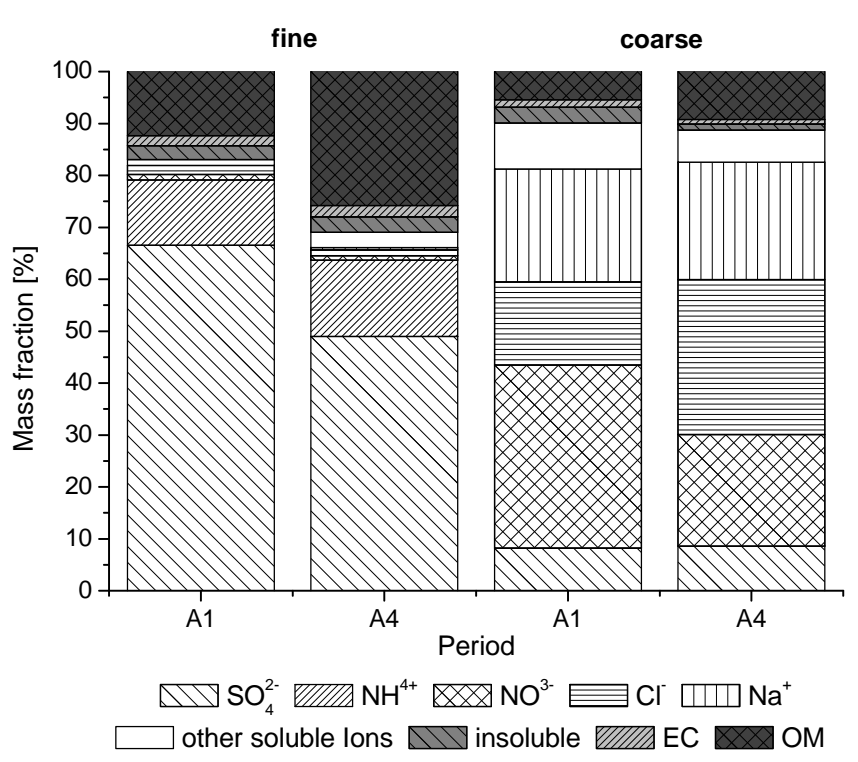

Fig. 6. Chemical composition of fine and coarse particles during the time periods A1 (marine) and A4 (continentally polluted).

The air masses during A1 and A3 originated in the western Mediterranean Sea (see Fig. 5), and showed only minor signs of continental influence. They are termed "marine" air masses in the following. The counterpart are the periods A2 and A4, during which the back trajectories pointed to continental source regions on the north-eastern shore of the Mediterranean (Fig. 5) and are therefore described as "continentally polluted" hereafter. Soot and total particle mass concentrations showed considerably higher levels compared to $\mathrm{A} 1$ and $\mathrm{A} 3$.

The size-fractionated chemical particle composition confirmed both, the systematic difference between fine and coarse particles, and slighter differences between different air mass types (see Fig. 6). Fine particles consisted overwhelmingly of ammonium sulphate and POM, coarse particles of sodium chloride and nitrate. Soot occurs in minor mass fractions between 2 and $6 \%$ only, as stated already in Fig. 2. The continentally influenced aerosol (A4) is distinguished from the rather marine aerosol (A1) by an elevated fraction of organic matter.

\subsection{Hygroscopic growth factor observations}

The hygroscopicity of fine particles was derived from the H-TDMA measurements, which revealed three groups of particles with different hygroscopic behavior: "more hygroscopic", "less hygroscopic" and "nearly hydrophobic". This finding is in broad agreement with previous H-TDMA observations (Swietlicki et al., 2008). Table 2 compiles the mean hygroscopic growth factors, their corresponding number fractions, soluble volume fractions and total soluble volume fractions with their standard deviations. As described in 


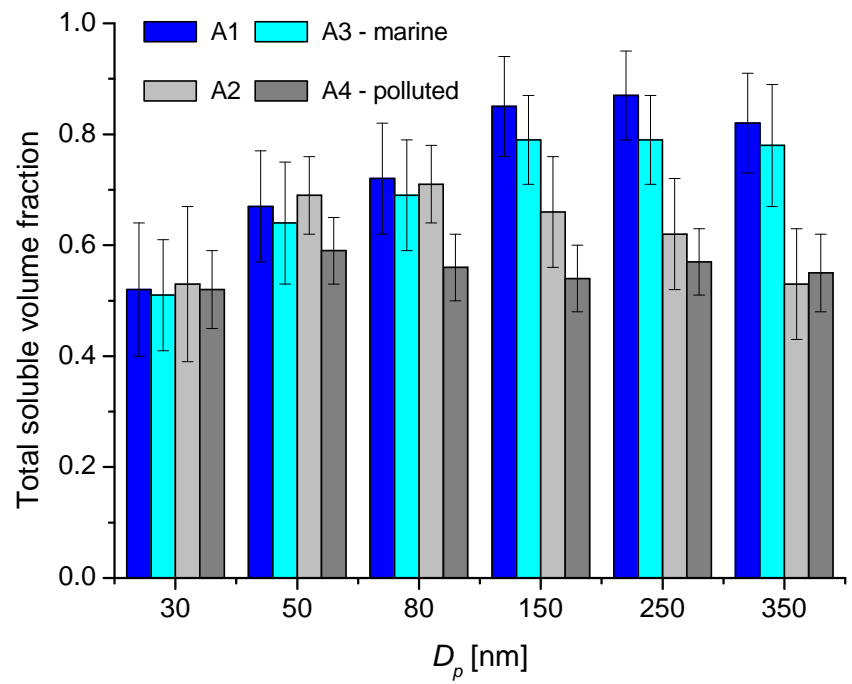

Fig. 7. Mean soluble volume fraction $\varepsilon_{\text {tot }}$ — based on the simplistic two-component model assuming insoluble matter and ammonium sulphate only (Sect. 3.2.1), as a function of particle size and air mass. Error bars indicate standard deviations of the mean.

Sect. 3.2.1, the soluble fractions are based on the assumption of a simplistic two-component model involving ammonium sulfate as the dominant soluble specie. Figure 6 supports this assumption for the fine particle mode for the two particular air masses A1 (marine) and A4 (continentally polluted). Figure 6 is consistent with former observations at Finokalia (Bardouki et al., 2000).

The hygroscopicity of coarse particles was assessed using the H-DMA-APS instrument. Because of the poor counting statistics of the H-DMA-APS measurements, leading to long integration times, a segregation of the data into the four classified air masses (A1-A4) was impossible. Instead, we only present mean values of the particle number fractions and aerodynamic growth factors for ARIADNE in Table 3.

In fact, the hygroscopic growth factor of the more hygroscopic particle group increased with an increasing particle diameter (Table 2). Furthermore, the number fraction of the more hygroscopic particles was about $80 \%$ in the sub- $\mu \mathrm{m}$ range and decreased to about $40 \%$ in the super-micrometer range $\left(D_{p}=1.2 \mu \mathrm{m}\right.$, see Table 3$)$. It has to be pointed out that the number fraction of the nearly hydrophobic particle group started to increase from about $10 \%$ in the sub-micrometer range at $D_{p}=250 \mathrm{~nm}$ to about $30 \%$ at $D_{p}=1.2 \mu \mathrm{m}$. While the mass in the fine particle fraction was clearly dominated by sulfate, the coarse fraction showed notable number contributions of insoluble particles, most likely dust particles.

\subsection{Soluble volume fractions using the two-component model}

Figure 7 visualises the soluble fraction $\varepsilon$ with its dependency of the air mass type. During the polluted time period, the sol- uble volume fraction is rather insensitive on particle diameter. The lower soluble volume fraction is also consistent with the increased amounts of organic matter (cf. Fig. 6). The soluble volume fractions of $30 \mathrm{~nm}$ show the lowest overall values, regardless of air mass type. This is suggestive of their physico-chemical properties being less influenced by longrange transport, and points to local sources or atmospheric secondary formation as the responsible source processes. $\varepsilon$ increased during the marine periods with increasing dry diameter for sub-micrometer aerosol.

\subsection{Relationship between hygroscopicity and soot}

In Fig. 8 the soluble volume fraction $\varepsilon$, determined from $\mathrm{H}$ TDMA measurements, is compared against the mass fraction of EC for the four air masses A1-A4. In general, the total soluble volume fraction decreased with increasing relative soot fraction. This effect was most visible for accumulation mode particles $\left(D_{p}=150,250\right.$, and $\left.350 \mathrm{~nm}\right)$. The lowest correlation coefficients were found for fine particles with diameters of 30 and $50 \mathrm{~nm}$. In contrast, $150 \mathrm{~nm}$ particles had the highest $R^{2}$ value of 0.74 . This might have a reason in the characteristic maximum of the soot number size distribution, which resides between 50 and $100 \mathrm{~nm}$. However, particles reaching the Finokalia measurement site are usually not freshly emitted but originate from faraway continental sources and are transformed by physical and chemical processes. The highest correlation between the insoluble particle volume and the soot fraction was found for particles with $D_{p}=100 \mathrm{~nm}$, i.e. where also the soot fraction was the highest. This result qualitatively agrees with the average size distribution for elemental carbon (EC) retrieved from size segregated chemical analysis, which is centered around $D_{p}=130 \mathrm{~nm}$ (see Fig. 9). For this assessment, the density of EC was estimated to be $1.9 \mathrm{~g} \mathrm{~cm}^{-3}$ (Fuller et al., 1999), which is necessary for the conversion of mass size to number size distributions.

\section{Aerosol scattering simulation results}

\subsection{Optical simulation under dry conditions: retrieval of refractive index}

As described in Sect. 3.3 and illustrated in Fig. 3, effective refractive indices of aerosol particles at dry conditions were one of the key parameters to initialize the optical simulations at ambient $\mathrm{RH}$. The $\tilde{m}_{\text {dry }}\left(n_{r}, n_{i}\right)$ were retrieved by the iterative Mie calculations using the best fit between the measured and calculated aerosol optical properties. Table 4 shows correlations between the seven calculated and measured optical properties $\left(\sigma_{j}^{c}\right.$ and $\left.\sigma_{j}^{e}\right)$ with slope $(b)$ and correlation coefficients $\left(R^{2}\right)$. (Note that all linear fits were forced through zero.)

Excellent agreement between $\sigma_{\text {ap }}^{c}$ and $\sigma_{\text {ap }}^{e}$ was found with $b$ of 0.99 and $R^{2}$ nearly 1.0. In general, the simulated and 
Table 2. Mean hygroscopic diameter growth factors, number fractions, and soluble volume fractions (based on a simplistic two-component model assuming insoluble matter and ammonium sulphate only) of each hygroscopic growth group during ARIADNE. The total soluble volume fraction and standard deviations of the mean are added for completeness.

\begin{tabular}{l|cccc}
\hline $\begin{array}{l}\text { Hygroscopic } \\
\text { growth group }\end{array}$ & $\begin{array}{c}\text { growth factor } \\
g f_{i}\end{array}$ & $\begin{array}{c}\text { number fraction } \\
n f_{i}\end{array}$ & $\begin{array}{c}\text { soluble volume } \\
\text { fraction }{ }^{1} \varepsilon_{i}\end{array}$ & $\begin{array}{c}\text { total soluble } \\
\text { volume fraction } \varepsilon_{\text {tot }}\end{array}$ \\
\hline $\begin{array}{l}D_{p}=30 \mathrm{~nm} \\
\text { More hygroscopic }\end{array}$ & $1.42 \pm 0.05$ & $0.79 \pm 0.17$ & $0.60 \pm 0.09$ & $0.52 \pm 0.12$ \\
$\begin{array}{l}\text { Less hygroscopic } \\
\text { Nearly hydrophobic }\end{array}$ & $1.24 \pm 0.05$ & $0.13 \pm 0.12$ & $0.31 \pm 0.07$ & \\
\hline$D_{p}=50$ nm & $1.04 \pm 0.06$ & $0.08 \pm 0.12$ & $0.04 \pm 0.06$ & \\
More hygroscopic & $1.51 \pm 0.06$ & $0.90 \pm 0.08$ & $0.70 \pm .011$ & $0.66 \pm 0.11$ \\
Less hygroscopic & $1.30 \pm 0.05$ & $0.06 \pm 0.05$ & $0.36 \pm 0.07$ & \\
Nearly hydrophobic & $1.12 \pm 0.07$ & $0.04 \pm 0.05$ & $0.12 \pm 0.08$ & \\
\hline$D_{p}=80$ nm & & & & \\
More hygroscopic & $1.56 \pm 0.06$ & $0.84 \pm 0.12$ & $0.74 \pm 0.11$ & \\
Less hygroscopic & $1.36 \pm 0.06$ & $0.09 \pm 0.07$ & $0.41 \pm 0.08$ & \\
Nearly hydrophobic & $1.17 \pm 0.08$ & $0.07 \pm 0.08$ & $0.17 \pm 0.09$ & \\
\hline$D_{p}=150$ nm & & & & \\
More hygroscopic & $1.59 \pm 0.07$ & $0.87 \pm 0.07$ & $0.76 \pm 0.13$ & \\
Less hygroscopic & $1.41 \pm 0.07$ & $0.07 \pm 0.05$ & $0.40 \pm 0.09$ & \\
Nearly hydrophobic & $1.18 \pm 0.08$ & $0.06 \pm 0.05$ & $0.17 \pm 0.08$ & \\
\hline$D_{p}=250$ nm & & & & \\
More hygroscopic & $1.63 \pm 0.07$ & $0.85 \pm 0.08$ & $0.80 \pm 0.14$ & \\
Less hygroscopic & $1.40 \pm 0.09$ & $0.07 \pm 0.06$ & $0.44 \pm 0.14$ & \\
Nearly hydrophobic & $1.19 \pm 0.08$ & $0.07 \pm 0.05$ & $0.18 \pm 0.09$ & \\
\hline$D_{p}=350$ nm & & & & \\
More hygroscopic & $1.63 \pm 0.08$ & $0.77 \pm 0.12$ & $0.81 \pm 0.15$ & \\
Less hygroscopic & $1.42 \pm 0.11$ & $0.10 \pm 0.08$ & $0.45 \pm 0.16$ & \\
Nearly hydrophobic & $1.18 \pm 0.08$ & $0.14 \pm 0.10$ & $0.16 \pm 0.08$ & \\
\hline & & & & \\
\hline
\end{tabular}

${ }^{1}$ based on a simplistic two-component model assuming insoluble matter and ammonium sulphate only.

Table 3. Mean hygroscopic diameter growth factors, number fractions and standard mean deviation for coarse particles with $D_{p}$ of 1.0 and $1.2 \mu \mathrm{m}$.

\begin{tabular}{l|cc}
\hline $\begin{array}{l}\text { Hygroscopic } \\
\text { growth group }\end{array}$ & $\begin{array}{c}\text { aerodynamic growth } \\
\text { factor } g f_{\text {aer }, i}\end{array}$ & $\begin{array}{c}\text { number fraction } \\
n f_{i}\end{array}$ \\
\hline $\begin{array}{l}D_{p}=1000 \mathrm{~nm} \\
\text { More hygroscopic }\end{array}$ & $1.20 \pm 0.04$ & $0.60 \pm 0.12$ \\
Less hygroscopic & $1.04 \pm 0.05$ & $0.12 \pm 0.07$ \\
Nearly hydrophobic & $1.03 \pm 0.05$ & $0.28 \pm 0.10$ \\
\hline$D_{p}=1200 \mathrm{~nm}$ & & \\
More hygroscopic & $1.31 \pm 0.14$ & $0.38 \pm 0.22$ \\
Less hygroscopic & $1.12 \pm 0.05$ & $0.31 \pm 0.18$ \\
Nearly hydrophobic & $1.09 \pm 0.08$ & $0.31 \pm 0.18$ \\
\hline
\end{tabular}

measured scattering coefficients followed each other very well. Also, all correlation coefficients $R^{2}$ were found to be greater than $\sim 0.95$. Except for $D_{p}=700 \mathrm{~nm}$, the deviations between the measured and calculated total/hemispheric back scattering coefficients were less than $\sim 7 \%$. Larger deviations occurred at $700 \mathrm{~nm}$. However, intercomparison studies of nephelometers in the laboratory also indicate that there might be higher uncertainties in the measured light scattering at $D_{p}=700 \mathrm{~nm}$ (Heintzenberg et al., 2006). On the basis of the comparison between the calculated and measured optical properties, it could be concluded that the retrieving model was suitable to provide time series of the refractive index and in general the retrieved $\tilde{m}_{\text {dry }}\left(n_{r}, n_{i}\right)$ were capable to well represent the measured particle scattering and absorption coefficients at dry conditions.

During our field study, different air masses were classified using back trajectory analysis (Sect. 4.1). In particular, air masses of marine origin from the western Mediterranean Sea and those influenced by continental emissions over southeastern Europe were distinguished (Table 1). Logically, the particle optical properties were also classified after this scheme: Figure 10 presents time series of the total 

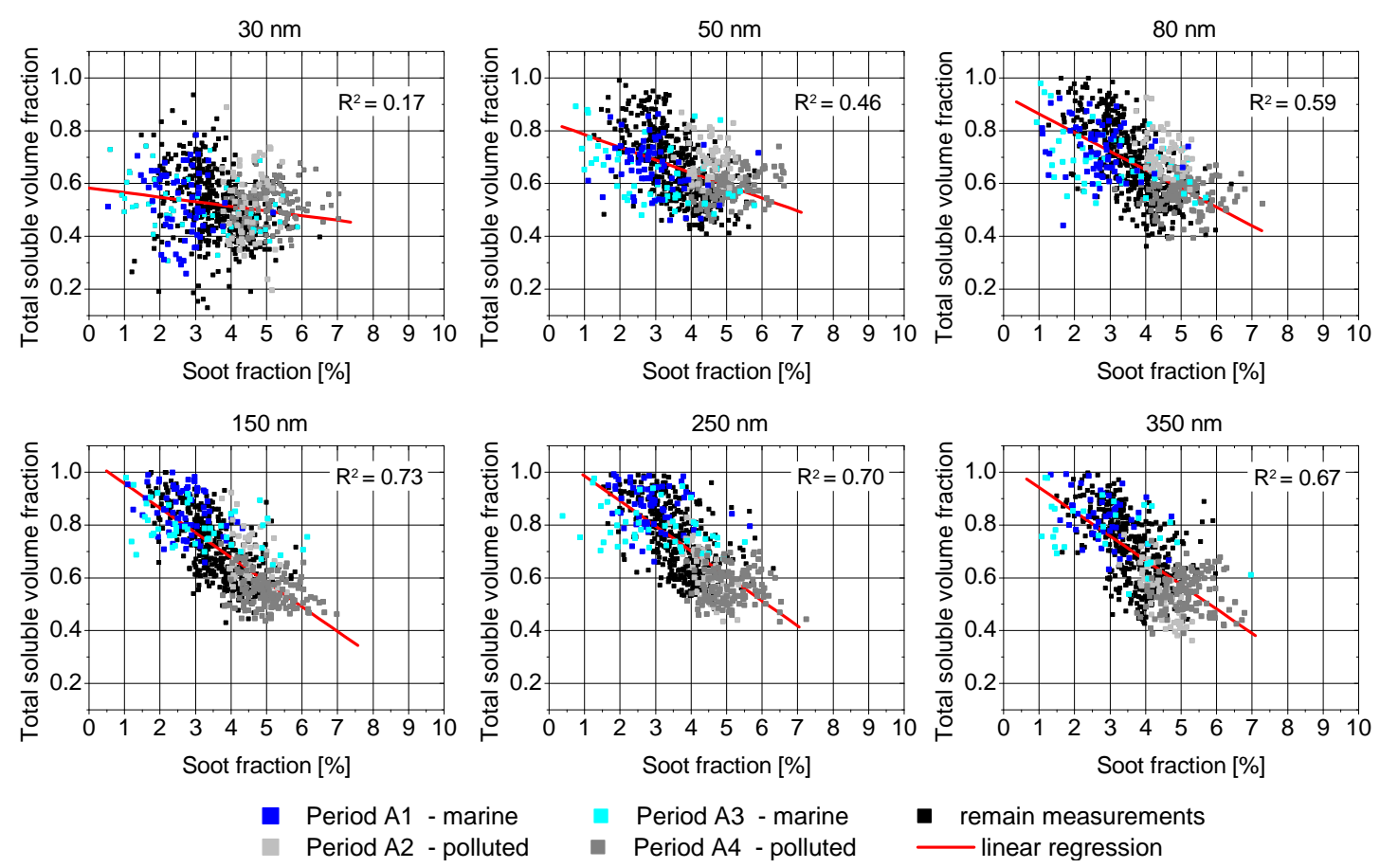

Fig. 8. Correlation between the soot mass fraction and the total soluble volume fraction $\varepsilon$ tot - derived from H-TDMA data and the simplistic two-component model assuming insoluble matter and ammonium sulphate only (Sect. 3.2.1).

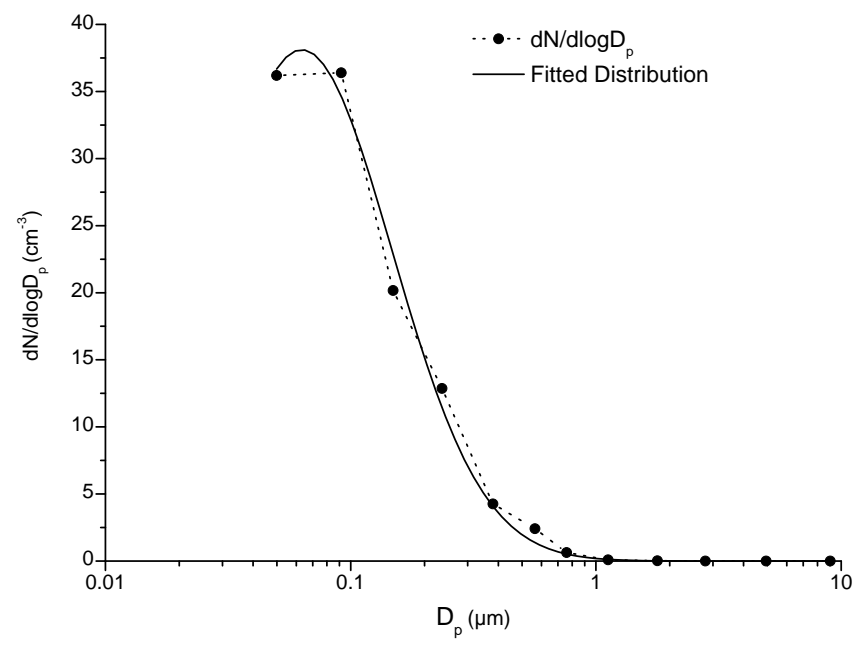

Fig. 9. Mean number size distribution for elemental carbon derived from size-segregated chemical analysis. The lognormal fit represents an approximation of the existing data points. Its geometric mean diameter bears some uncertainty because of the open left-hand side of the distribution.

scattering coefficient at $550 \mathrm{~nm}\left(\sigma_{\mathrm{sp}, \mathrm{neph}, 550 \mathrm{~nm}}\right)$ and absorption coefficient at $630 \mathrm{~nm}\left(\sigma_{\mathrm{ap}, \mathrm{MAAP}}, 630 \mathrm{~nm}\right)$ measured by the nephelometer and the MAAP, as well as the retrieved $n_{r}$ and $n_{i}$. More detailed statistic information for these parameters during the two different periods were summarized in Table 5.
Table 4. Correlation between calculated and measured optical properties $\left(\sigma_{j}^{c}\right.$ and $\left.\sigma_{j}^{e}\right)$. Here, $\sigma_{j}^{c}=b \cdot \sigma_{j}^{e}$, with adjusted correlation coefficient $\left(R^{2}\right)$.

\begin{tabular}{c|cc}
\hline & Slope (b) & $R^{2}$ \\
\hline$\sigma_{\mathrm{sp}, 450 \mathrm{~nm}}$ & 0.999 & 0.992 \\
$\sigma_{\mathrm{sp}, 550 \mathrm{~nm}}$ & 1.069 & 0.995 \\
$\sigma_{\mathrm{sp}, 700 \mathrm{~nm}}$ & 1.197 & 0.992 \\
$\sigma_{\mathrm{bsp}, 450 \mathrm{~nm}}$ & 0.949 & 0.979 \\
$\sigma_{\mathrm{bsp}, 550 \mathrm{~nm}}$ & 0.915 & 0.986 \\
$\sigma_{\mathrm{bsp}, 700 \mathrm{~nm}}$ & 0.888 & 0.948 \\
$\sigma_{\mathrm{ap}, 630 \mathrm{~nm}}$ & 0.991 & 0.999 \\
\hline
\end{tabular}

As shown in Fig. 10, the measured scattering and absorption coefficients show a concurrent time evolution. However, the respective values were significantly lower for marine air masses (see Fig. 10 and Table 5) compared to continentally polluted periods. This was mainly due to the lower mass concentrations of sub- $\mu \mathrm{m}$ particles measured during the marine periods. Real parts of the retrieved refractive indices were very similar for both air mass types (marine $\sim 1.48$ and continentally polluted $\sim 1.50$ ), whereas the average imaginary part was a factor of 2 lower for marine air masses (see Table 5). The real and imaginary parts of refractive index were highly variable for marine air masses, possibly due to individual emission sources such as ships. 


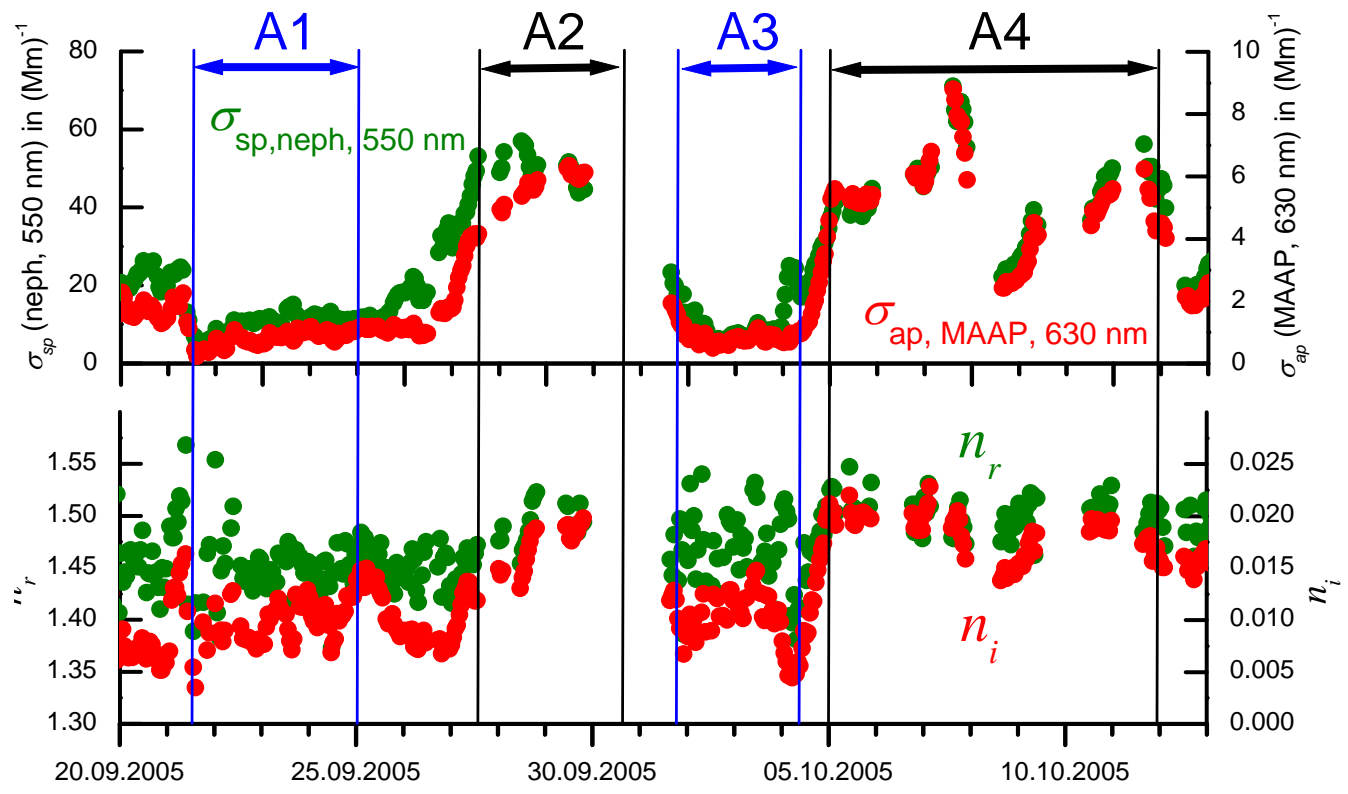

Fig. 10. Optical measurements and simulations at dry conditions. Upper graph: total scattering coefficients at $550 \mathrm{~nm}\left(\sigma_{\mathrm{sp}, \mathrm{neph}, 550 \mathrm{~nm})}\right)$ and

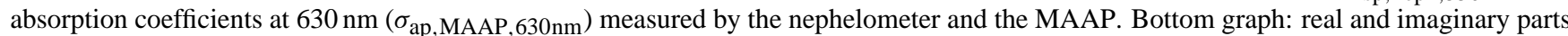
of the retrieved refractive indices $\left(n_{r}\right.$ and $\left.n_{i}\right)$. Periods covering marine (A1, A3) and continentally polluted air masses (A2, A4) are marked.

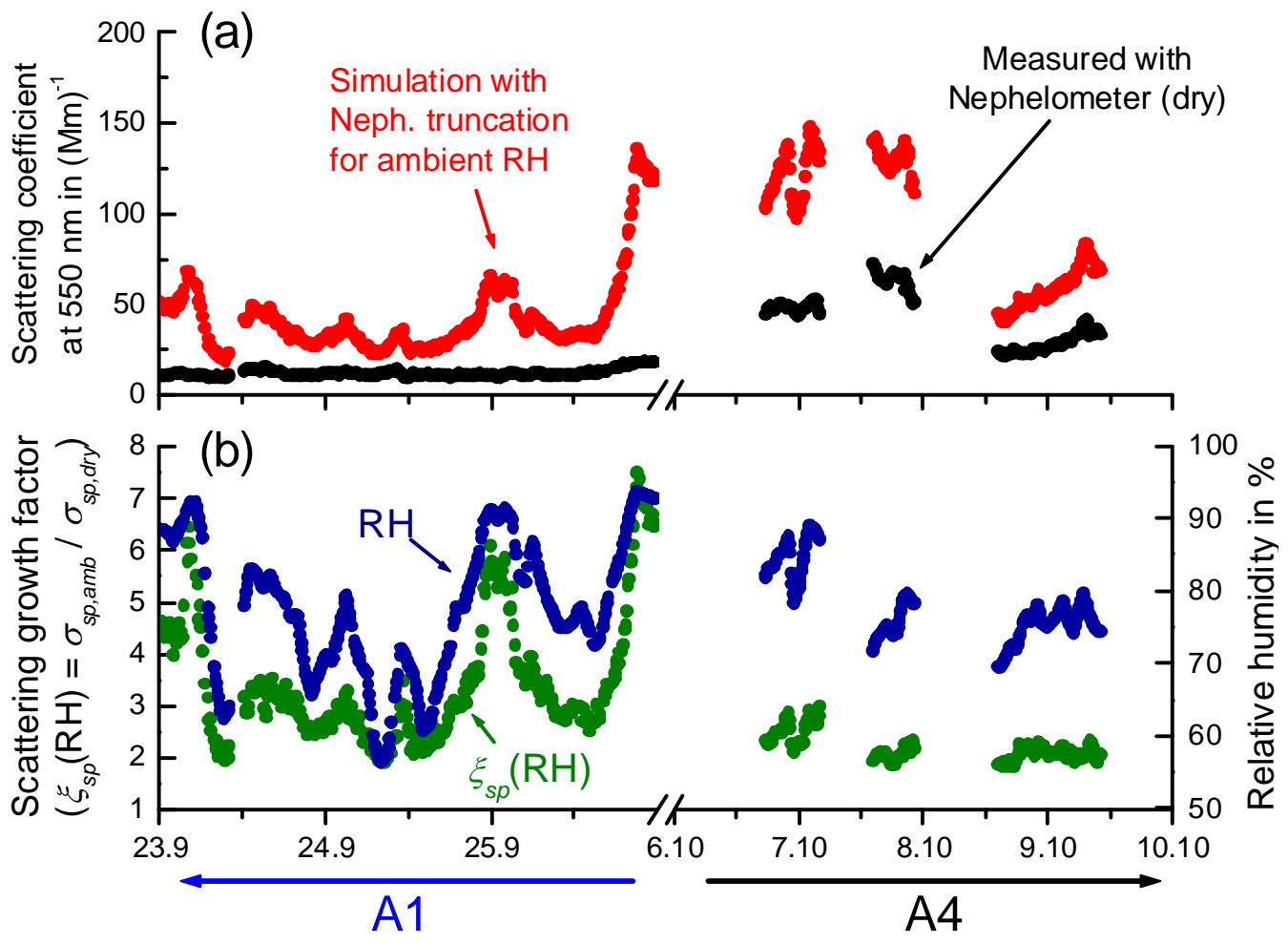

Fig. 11. Optical simulations under ambient conditions for both marine (A1, 23-25 September 2005) and continentally polluted (A4, 6-9 October 2005) cases: (a) simulated aerosol scattering coefficient $(550 \mathrm{~nm})$ under ambient conditions vs. the aerosol scattering coefficient $(550 \mathrm{~nm})$ measured by a nephelometer at dry conditions. (b) ambient RH and scattering growth factor $\left(\xi_{\mathrm{sp}}(\mathrm{RH})=\sigma_{\mathrm{sp}, \mathrm{amb}} / \sigma_{\mathrm{sp}, \mathrm{dry}}\right)$. The experimental scattering coefficients were corrected for the non-idealities (truncation) of the nephelometer. 
Table 5. Mean values of measured total scatter and absorption coefficients $\left(\mathrm{Mm}^{-1}\right)$ and retrieved refractive index, divided into marine air masses and continentally polluted air masses.

\begin{tabular}{r|cc} 
& Marine & Continental Polluted \\
\hline $\bar{\sigma}_{\mathrm{sp}, 450 \mathrm{~nm}}$ & $16 \pm 6$ & $63 \pm 15$ \\
$\bar{\sigma}_{\mathrm{sp}, 550 \mathrm{~nm}}$ & $10 \pm 4$ & $44 \pm 11$ \\
$\bar{\sigma}_{\mathrm{sp}, 700 \mathrm{~nm}}$ & $6 \pm 2$ & $26 \pm 6$ \\
\hline $\bar{\sigma}_{\mathrm{bsp}, 450 \mathrm{~nm}}$ & $1.8 \pm 0.6$ & $6.9 \pm 1.5$ \\
$\bar{\sigma}_{\mathrm{bsp}, 550 \mathrm{~nm}}$ & $1.5 \pm 0.5$ & $5.7 \pm 1.2$ \\
$\bar{\sigma}_{\mathrm{bsp}, 700 \mathrm{~nm}}$ & $1.2 \pm 0.5$ & $4.5 \pm 1.0$ \\
\hline $\bar{\sigma}_{\mathrm{ap}, 630 \mathrm{~nm}}$ & $0.8 \pm 0.3$ & $5.2 \pm 1.3$ \\
\hline $\bar{n}_{r}$ & $1.48 \pm 0.04$ & $1.50 \pm 0.02$ \\
$\bar{n}_{i}$ & $0.01 \pm 0.003$ & $0.02 \pm 0.002$ \\
\hline
\end{tabular}

\subsection{Optical simulation at ambient RH}

For the optical simulations at ambient $\mathrm{RH}$, two individual cases were chosen: the marine air mass A1 (23-25 September 2005) and the continentally polluted air mass A4 (6-9 October 2005) (cf. Table 1). With the methods introduced in Sect. 3.3, average particle hygroscopic growth factors of marine and continentally polluted periods were respectively applied to these two cases. Figure 11 presents the time series of the calculated aerosol scattering coefficient at $\lambda=550 \mathrm{~nm}$ at ambient RH together with the measured values by the nephelometer at dry conditions. In addition, on can see ambient $\mathrm{RH}$ and the scattering growth factor, defined as the scattering coefficient at ambient $\mathrm{RH}$ divided by that at dry conditions: $\left.\xi_{\mathrm{sp}}(\mathrm{RH})=\sigma_{\mathrm{sp}, \mathrm{amb}} / \sigma_{\mathrm{sp}, \mathrm{dry}}\right)$. The truncation of the nephelometer was taken into account in the optical simulations. Data gaps during the continentally polluted period were due to missing data of the measured aerosol optical properties.

In summary, a pronounced enhancement of particle scattering due to particle hygroscopicity was found during both, the marine and the continentally polluted cases. $\xi_{\mathrm{sp}}$ basically followed the pattern of RH (Fig. 11).

\subsection{Amplification of aerosol scattering by RH}

In Fig. 12, the $\xi_{\mathrm{sp}}$ are plotted as a function of $\mathrm{RH}$ for both cases. When the marine air masses dominated at Finokalia, the $\xi_{\mathrm{sp}}(80 \%)$ ranged from 2.7 to 3.5 . This is consistent with the measured scattering growth factor at $\mathrm{RH} 80 \%$ for sea salt and $\left(\mathrm{NH}_{4}\right)_{2} \mathrm{SO}_{4}$ (3.4 and 2.2, respectively) (Covert et al., 1972), since the aerosol composition was dominated by sea salt particles combined with some fractions of ammonium sulfate. In marine air the aerosol scattering coefficient varied with RH as theoretically expected from sea salt particles. However, it is worth noticing that $\xi_{\mathrm{sp}}(80 \%)$ for the marine case at Finokalia station was higher than the values of clean marine aerosols (1.8-2.5) reported by previous studies at other locations.

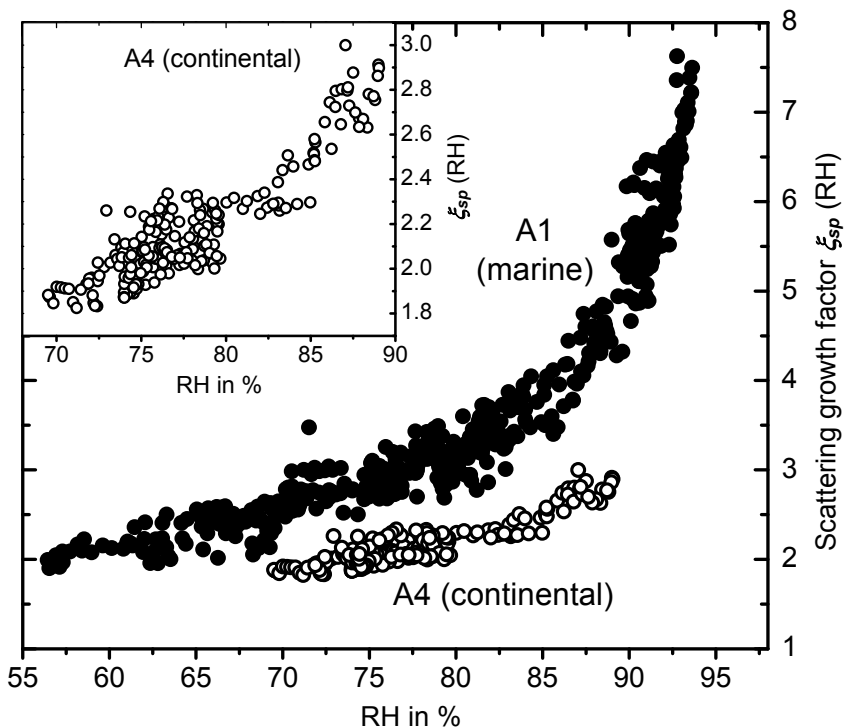

Fig. 12. Growth factors of particle scattering $\left(\xi_{\mathrm{sp}}(\mathrm{RH})=\sigma_{\mathrm{sp}, \mathrm{amb}} / \sigma_{\mathrm{sp}, \text { dry }}\right)$ as a function of relative humidity (RH). The data sets were classified into two cases, marine (23-25 September 2005) and continentally polluted (6-9 October 2005), with a subset containing the zoom-in pattern of the continentally polluted case.

For example, the reported $\xi_{\mathrm{sp}}(80 \%)$ for clean marine periods at Cape Grim, Tasmania were $2.0 \pm 0.2$ and $2.5 \pm 0.2$ (measured using a humidified nephelometer; Carrico et al., 1998) and the respective values were on average 2 in Seattle (Covert et al., 1972), 2.09 off the mid-Atlantic coast of the United States (Kotchenruther et al., 1999), and 2.3 \pm 0.3 in clean marine air near the coast of California and Washington. Moreover, for higher RH during the marine case at Finokalia, the simulated amplification of scattering due to particle water uptake could be as large as a factor of 5 at $90 \% \mathrm{RH}$ and 7-8 at $95 \% \mathrm{RH}$.

We emphasize that in our experimental work, the aerosol sample was always humidified to more than $90 \%$ RH before the hygroscopic growth factors were measured. This ensures that the particles have a deliquescence history, i.e. originate from the upper branch of the hysteresis. This picture also refers to the radiative transfer modelling, where the aerosol is assumed to have been in a state of high RH. (This is reasonable in view of the marine atmosphere surrounding Crete.) Therefore, our considerations are not sensitive to deliquescence, as is the case when moving from an originally dry aerosol to higher $\mathrm{RH}$.

Compared to the clean marine case, the chemical particle composition during the continentally polluted periods at the Finokalia site consisted of a relatively more complicated mixture of various chemical compounds and also the variation in particle number size distribution was higher. Referring to Fig. 12, the differences in $\xi_{\text {sp }}$ between marine and continentally polluted cases are significant. The scattering 
growth factors during the continentally polluted case were always much smaller than those during the marine case, regardless of the variation of $\mathrm{RH}$. Also, the amplification rate of scattering with increasing RH during the continentally polluted case was lower than that during the marine case. At RH $90 \%$, the $\xi_{\text {sp }}$ during continentally polluted periods was less than 3 (see the zoom-in subset in Fig. 12), whereas the respective growth during the marine period reached up to about a factor of 5. A strong enhancement of particle scattering due to water uptake at $\mathrm{RH}>90 \%$ was observed in marine-type air; unfortunately, no case of similarly high RH was observed during ARIADNE in polluted air that could serve for a direct comparison.

When comparing previous aerosol optical studies, one can conlude that $\xi_{\mathrm{sp}}(80-85 \%$ varies in the atmosphere with time, space, and aerosol type (Covert et al., 1972; Sloane and Wolff, 1985; Malm et al., 1994; Hegg et al., 1996; Tang, 1996; Li-Jones et al., 1998; Kotchenruther and Hobbs, 1998; Kotchenruther et al., 1999; Gassó et al., 2000; KoloutsouVakakis et al., 2001; Im et al., 2001; Hegg et al., 2002; Sheridan et al., 2002; Randriamiarisoa et al., 2006; Bundke et al., 2002; Nessler et al., 2005; Raut and Chazette, 2007; Cheng et al., 2008). The reported literature values range from 1.8 to 2.5 for clean marine aerosols, 1.58 to 1.81 for polluted marine aerosols, 1.4 to 1.65 for anthropogenic aerosols, $\sim 1.0$ to 1.13 for dust aerosols and $\sim 1.1$ to 1.4 for fresh biomass burning particles. As global average, $1.7 \pm 0.3$ was used by Charlson et al. (1991) for anthropogenic sulfate aerosols in a 3-dimensional global model. Our results for the continentally polluted case were found to be higher than those reported for polluted marine aerosols and anthropogenic aerosols in other studies. This may indicate a relatively significant influence of marine aerosols during the continentally polluted period.

As the respective average size-segregated hygroscopic growth law was applied overall to individual cases (marine or continentally polluted cases), we evaluated the influence of the dry particle number size distributions on the particle scattering growth. Thus, the effective diameter $D_{p \text {, eff }}$ of fine particle number size distributions $(<1 \mu \mathrm{m})$ at dry conditions was calculated as the quotient of the total particle volume $V$ and the total surface area $S$.

As illustrated in Fig. 13, the most efficient scattering amplification in terms of the maximums of $\xi_{\text {sp }}$ occurred when the particle effective diameter $(<1 \mu \mathrm{m})$ was between 250 and $280 \mathrm{~nm}$ when the RH was below $80 \%$ for the marine case. If the RH was higher than $80 \%$, the scattering coefficient of particles with smaller $D_{p \text {, eff }}(220-230 \mathrm{~nm})$ grew effectively too. The pattern of scattering growth factors during the continentally polluted case was more complex than that of the marine case, which might be due partially to the small number of data points and the smoothing method. The most effective scattering amplification occurred at effective diameters between 260 and $300 \mathrm{~nm}$. A similar behavior of particles with smaller $D_{p \text {,eff }}(240-260 \mathrm{~nm})$ has also been found during the continentally polluted case. Tang (1996) investigated the
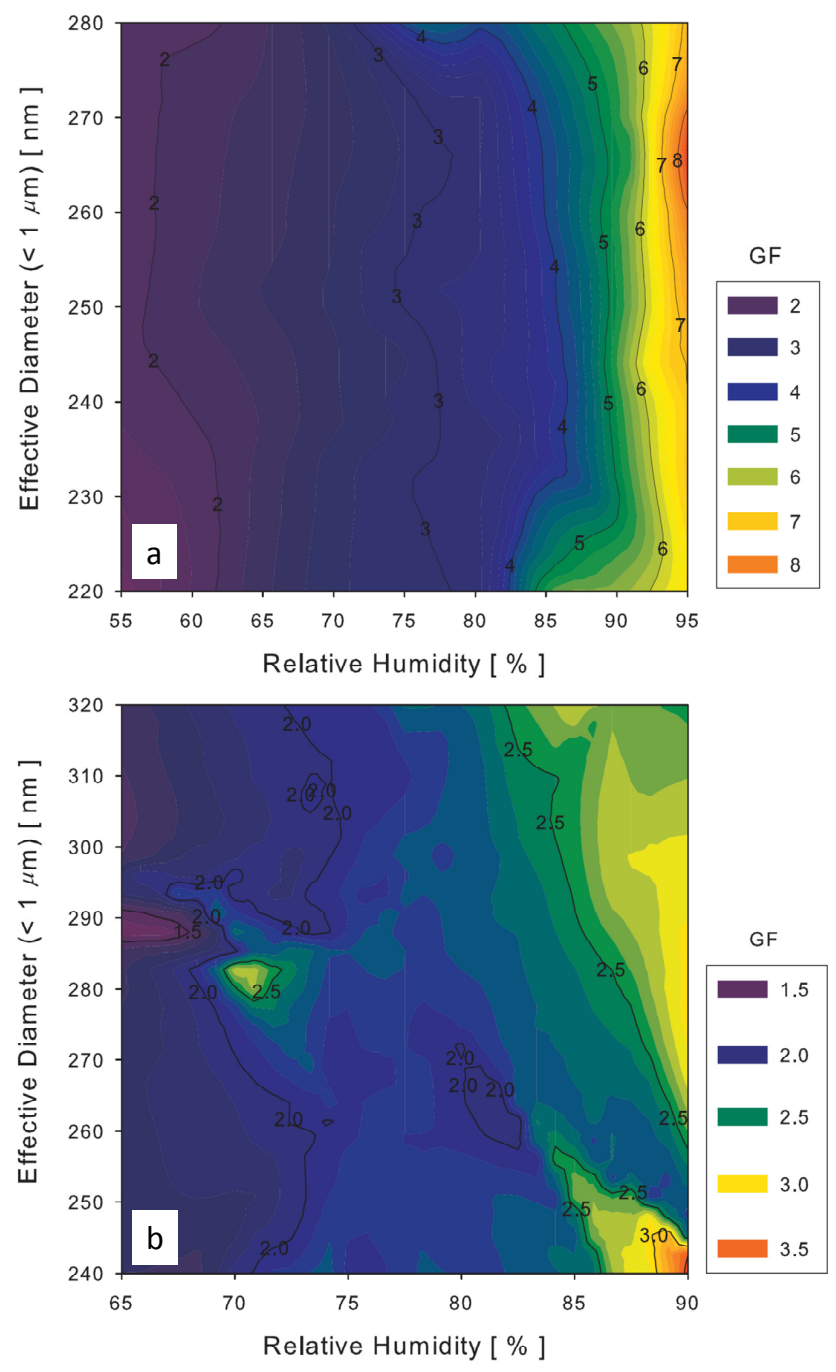

Fig. 13. Contour plots of scattering growth factors $\left(\xi_{\mathrm{sp}}(\mathrm{RH})=\sigma_{\mathrm{sp}, \mathrm{amb}} / \sigma_{\mathrm{sp}, \text { dry }}\right)$ as a function of relative humidity and effective diameter $\left(D_{p, \text { eff }}\right)$ of the submicrometer particle number size distributions at dry conditions for (a) marine (A1, 23-25 September 2005) and (b) continentally polluted (A4, 6-9 October 2005) cases. The data sets were smoothed by the Loess method.

size-effects of hygroscopic behavior on $\sigma_{\mathrm{sp}}$ with numerical methods. They found that assuming the same standard deviation of particle number size distributions, the increase of $\sigma_{\text {sp }}$ with RH was smaller for the particles with a mean geometric diameter of $0.6 \mu \mathrm{m}$ compared to that for particles with a geometric mean diameter of $0.3 \mu \mathrm{m}$. Nessler et al. (2005) also stated that due to the particle size dependence of $\sigma_{\mathrm{sp}}$, the humidity effect on $\sigma_{\mathrm{sp}}$ was more intense for the smaller particles within the mid-visible $\lambda$ range.

Our results suggest that at under typical daytime $\mathrm{RH}$ at Finokalia (70-80\%), a significant fraction of up to $\sim 50-70 \%$ ) of the visibility degradation (as assessed by light extinction) is caused by the uptake of water by the particles compared to the dry particle state. 


\subsection{Aerosol radiative forcing calculations}

In order to estimate and compare the aerosol radiative forcing $\Delta F_{r}$ caused by the aerosol in the different air masses under study, a simplistic two-layer-single-wavelength radiative transfer model was used (Chýlek and Wong, 1995). According to this model:

$\Delta F_{r}=-\frac{1}{2} S_{0}\left[T_{\mathrm{atm}}^{2}\left(1-A_{C}\right)\right]\left[\left(1-R_{S}\right)^{2} \bar{\beta} \tau_{\mathrm{sp}}-2 R_{S} \tau_{\mathrm{ap}}\right]$

Here, the factor $\frac{1}{2}$ accounts for the partial length of the day, $S_{0}=1370 \mathrm{~W} \mathrm{~m}^{-2}$ is the solar constant, $T_{\text {atm }}$ the transmittance of the atmosphere above the aerosol layer with a global average of $\sim 0.76, A_{C}$ the fraction of sky covered by clouds, $R_{s}$ the surface albedo of the underlying ground- $\tau_{\mathrm{sp}}$ and $\tau_{\text {ap }}$ are the optical thicknesses of the aerosol layer due to light scattering and absorption, respectively, and $\bar{\beta}$ is the average upscatter fraction.

Finokalia is located on Crete in the eastern Mediterranean, south of continental Greece (Fig. 1). For the open Aegean Sea in this region, an average planetary boundary layer (PBL) height of $400 \mathrm{~m}$ is typically reported for this time of the year (Kallos et al., 1998). Vardavas and Taylor (2007) indicated that the sea albedo depends on the solar zenith angle (Fresnel reflection), and whether or not the sky is cloudy. For cloudy sky (diffuse radiation), the authors report the sea albedo to be about 0.055 , for clear sky for overhead sun about 0.021 climbing up to about 0.8 when the sun is low on the horizon. However, for a rough water surface it does not go beyond 0.3 (Vardavas and Taylor, 2007). A mean value of 0.06 was chosen in the model simulations of the present study. The radiative cloud fraction images retrieved from OMI (Ozone Monitoring Instrument) satellite observations (data retrieved from (http://toms.gsfc.nasa.gov/reflect/ reflect_v8.html) were checked for the August to October period of 2005. It was confirmed that there were almost no clouds over the Aegean Sea most of the time. Less than $20 \%$ of the days showed thin and only partial cloud covers over the open Aegean sea. So the $A_{C}$ could be safely set to zero in the radiative calculations.

Wiscombe and Grams (1976) and Marshall et al. (1995) investigated relationships between the asymmetry parameter $g$ and $\bar{\beta}$. For the Mie simulation of the aerosol scattering and absorption at ambient conditions, $g$ was also calculated for the particles at ambient conditions. $\bar{\beta}(\mathrm{RH})$ were therefore calculated with $g_{\mathrm{amb}}$ at $550 \mathrm{~nm}$ by using the HenyeyGreenstein phase function (Wiscombe and Grams, 1976).

The calculated time series of the aerosol single scattering albedo $\omega_{0,550 \mathrm{~nm}, \mathrm{amb}}\left(=\sigma_{\mathrm{sp}, 550 \mathrm{~nm}, \mathrm{amb}} /\left(\sigma_{\mathrm{sp}, 550 \mathrm{~nm}, \mathrm{amb}}+\right.\right.$ $\left.\left.\sigma_{\mathrm{ap}, 550 \mathrm{~nm}, \mathrm{amb}}\right)\right)$ and the uperscatter fraction $\left(\bar{\beta}_{550 \mathrm{~nm}, \mathrm{amb}}\right)$ at ambient conditions for both marine and continentally polluted cases are presented in Fig. 14. The average ambient $\omega_{0,550 \mathrm{~nm}}$ was generally higher during the marine period $(\sim 0.97 \pm 0.01)$ compared to the continentally polluted period

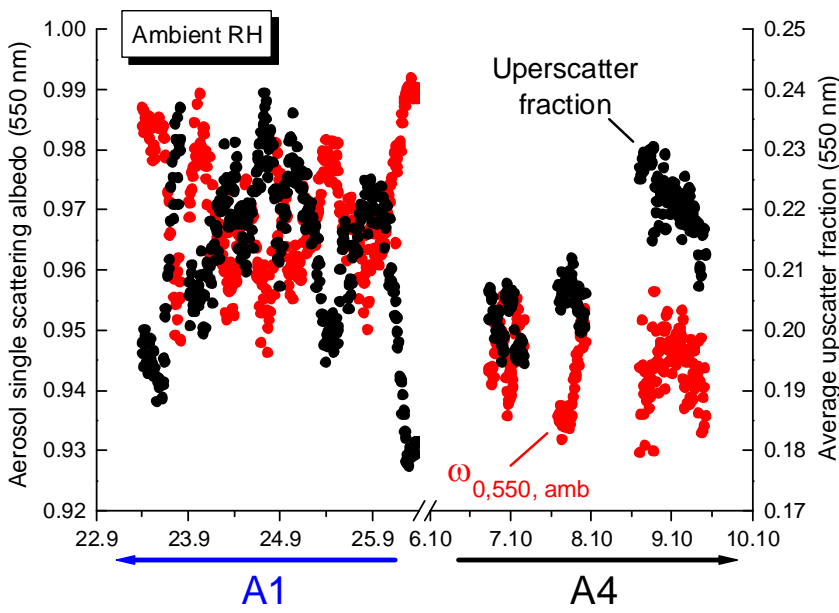

Fig. 14. Time series of the calculated aerosol single scattering albedo $\left(\omega_{0,550 \mathrm{~nm}, \mathrm{amb}}\right)$ and estimated upscatter fraction $\left(\bar{\beta}_{550 \mathrm{~nm}, \mathrm{amb}}\right)$ at ambient $\mathrm{RH}$ for both marine (A1) and continentally polluted (A4) cases.

$(\sim 0.94 \pm 0.01)$. As the particles grow with increasing $\mathrm{RH}$, the forward scattering increases too, which means that the back scattering and upscatter fraction decrease (Cheng et al., 2008). During marine periods, when the RH reached up to $92 \%$ (see Fig. 11), $\bar{\beta}$ dropped down from $\sim 0.23$ to 0.18 . The average values of $\bar{\beta}$ for marine and continentally polluted periods were comparable $(\sim 0.21 \pm 0.02$ and $0.21 \pm 0.01$, respectively).

To estimate the aerosol direct radiative forcing we made the assumption that the aerosol particles were mixed homogenously within the PBL during daytime of the studied period at the open Aegean Sea between Crete and continental Greece. Accordingly, the calculated aerosol scattering and absorption coefficients at ambient conditions were simply integrated along the PBL height to retrieve $\xi_{\text {sp }}(\mathrm{RH})$ and $\xi_{\text {ap }}(\mathrm{RH})$. Figure 15 shows the calculated aerosol direct radiative forcing $\left(\Delta F_{\mathrm{r}}\right)$ during marine and continentally polluted periods based on our simulations. The aerosol direct radiative forcings during both periods were negative indicating a net "cooling" effect. Most of the time, the strength of forcing was dominated by total aerosol concentration, i.e. the higher the aerosol concentration, the stronger the forcing. $\Delta F_{\mathrm{r}}$ of continentally polluted aerosols was most of the time stronger compared to that of marine aerosols (ca. -4 versus $-1.5 \mathrm{~W} \mathrm{~m}^{-2}$ ). The $\Delta F_{\mathrm{r}}$ shows an anticorrelation with ambient $\mathrm{RH}$ during the marine period (the higher the $\mathrm{RH}$, the stronger the forcing), whereas the respective pattern between $\Delta F_{\mathrm{r}}$ and $\mathrm{RH}$ was not as clear during the continentally polluted period, when the variation was mainly dominated by the changing aerosol concentration. This result is supported by the fact that marine aerosols are suspected to be highly hygroscopic compared to continental anthropogenic aerosols. Part of the differences are also due to particle size effects, i.e. 


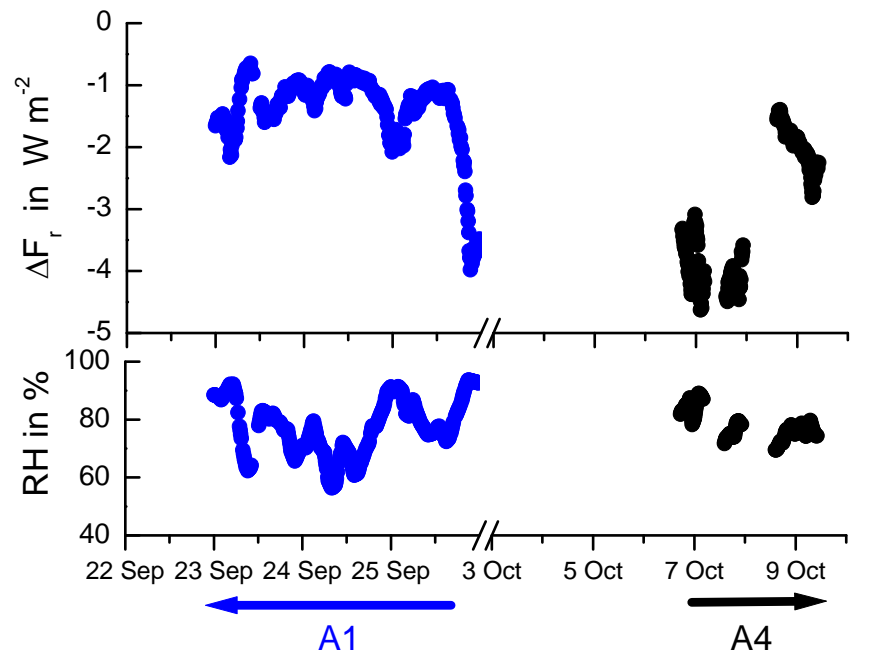

Fig. 15. Time series of the calculated aerosol direct radiative forcing $\left(\Delta F_{\mathrm{r}}\right)$ at ambient conditions as well as the ambient $\mathrm{RH}$ for both marine (A1) and continentally polluted (A4) cases.

the increased forward scattering and thus decreased upscattering fraction of the larger marine aerosol particles. When RH reached $90 \%$ and more at the end of period A1, the $\Delta F_{\mathrm{r}}$ intensified to the same level as during continentally polluted periods (ca. $-4 \mathrm{~W} \mathrm{~m}^{-2}$ ) or even stronger (ca. $-7 \mathrm{~W} \mathrm{~m}^{-2}$ ). It is worthwhile to note that another general reason for the remarkable negative forcings is the poorly absorbing nature of the particles, manifested by the low overall BC concentrations.

\section{Conclusions}

This paper presents physical and chemical parameters of aerosol particles collected between August and October 2005 in Finokalia on the northern coast of Crete, Greece. The central goal was to quantify the hygroscopic growth of atmospheric aerosol particles over the Eastern Mediterranean and assess its potential influence on particle light scattering at ambient relative humidty (RH). The H-TDMA and H-DMA-APS instruments revealed the presence of three different hygroscopic particle groups both in the fine and coarse particle modes. At $90 \% \mathrm{RH}$, the diameter growth factors of the more hygroscopic group ranged between 1.4 and 1.63, increasing monotonously with mobility diameter $\left(D_{p}\right)$ from 30 to $350 \mathrm{~nm}$. The observed values were within the broad range indicated by global H-TMDA observations (Swietlicki et al., 2008). Substantially lower growth factors were encountered for the more hygroscopic fraction at $D_{p}=1.0$ and $1.2 \mu \mathrm{m}$, which rules out sea salt as the only component present in this intermediate size range between the fine and coarse particle mode.
The measurement period was separated into four consecutive time periods (A1-A4) based on air mass origin and the soot mass fraction measured by the MAAP instrument. The two clean marine air masses (A1 and A3) originated in the western Mediterranean Sea while the two continentally polluted air masses (A2 and A4) had passed over southeastern Europe and the Black Sea. The differences between these air masses could be clearly seen in the H-TMDA data: Clean marine air masses contained particles with higher diameter growth factors in the accumulation mode range than continentally influenced air masses. These differences were supported by variations in chemical particle composition, manifested mainly by a higher fraction of particulate organic matter $(\mathrm{POM})$ in continentally influenced air.

In the second part of our study, the measured particle hygroscopic growth factors were used to simulate aerosol light scattering at ambient conditions. Generally, a pronounced enhancement of particle light scattering due to the particle's hygroscopic water uptake was found both for the marine and continentally polluted cases. When the marine air masses dominated at Finokalia, the scattering enhancement factor $\xi_{\mathrm{sp}}$ ( $80 \%$ ) ranged between 2.7 and 3.5, close to the values anticipated for sea-salt particles. At extremely high RH, the simulated amplification of scattering due to water uptake during the marine periods was calculated to be as large as a factor of 5 at $\mathrm{RH} 90 \%$ and 7 to 8 at $\mathrm{RH} \sim 95 \%$.

The differences in $\xi_{\text {sp }}$ between the marine and continentally influenced cases were significant: During the continentally polluted case the $\xi_{\mathrm{sp}}$ were always much smaller than those during the marine case, regardless of the variation in RH. Also, the amplification rate of scattering with increasing RH during the continentally polluted case was lower than that of the marine case. At RH $90 \%$, the $\xi_{\text {sp }}$ during the continentally polluted period was less than 3 , whereas the respective growth during the marine period reached up to about a factor of 5 . The $\xi_{\text {sp }}(80 \%)$ for the continentally polluted case were found to be higher than those reported for polluted marine aerosols and anthropogenic aerosols in other studies. This may indicate a relatively larger influence of marine aerosols even though it was identified as continentally polluted period. Our results implied that at typical RH during daytime a high fraction of the visibility degradation was due to the water uptake of hygroscopically active material.

The calculated single scattering albedo for ambient conditions $\omega_{0 ; 550 \mathrm{~nm}}$ was generally higher during the marine period $(\sim 0.97 \pm 0.01)$ compared to the continentally polluted period $(\sim 0.94 \pm 0.01)$. During marine periods, when the $\mathrm{RH}$ reached up to $92 \%, \bar{\beta}$ dropped from $\sim 0.23$ to 0.18 . In both cases, however, the estimated aerosol direct radiative forcings were negative, thus indicating a net "cooling" effect. In general, the strength of the forcing was governed by the aerosol concentration during most of the time, with minor contributions by the particle size distribution shape. The forcing anti-correlated with ambient $\mathrm{RH}$ during the marine period, whereas the respective pattern between $\Delta F_{\mathrm{r}}$ and $\mathrm{RH}$ 
was not as clear during the continentally polluted period. In the latter case, the variation was mainly dominated by the variation of aerosol concentrations.

Acknowledgements. This work was supported by the German Academic Exchange Service DAAD (PPP programme with Greece) and Atmospheric Composition Change - The European Network of Excellence (ACCENT). The authors acknowledge the NOAA Air Resources Laboratory (ARL) for the provision of the HYSPLIT transport and dispersion model (http://www.arl.noaa.gov/ready/hysplit4.html) used in this publication. Parts of the data evaluation for this paper were conducted within the European Integrated project on Aerosol Cloud Climate and Air Quality Interactions (EUCAARI), coordinated by the University of Helsinki. We finally thank the two anonymous reviewers who considerably helped improve the manuscript.

Edited by: V.-M. Kerminen

\section{References}

Ansari, A. S. and Pandis, S.: Water absorption by secondary organic aerosol and its effect on inorganic aerosol behavior, Env. Sci. Technol., 34, 71-77, 2000.

Anderson, T. L. and Ogren, J. A.: Determining aerosol radiative properties using the TSI 3563 Integrating Nephelometer, 29, 5769, 1998.

Anderson, T. L., Covert, D. S., Marshall, S. F., Laucks, M. L., Charlson, R. J., Waggoner, A. P., Ogren, J. A., Caldow, R., Holm, R. L., Quant, F. R., Sem, G. J., Wiedensohler, A., Ahlquist, N. A., and Bates, T. S.: Performance characteristics of a high-sensitivity, three-wavelength, total scatter/backscatter nephelometer, J. Atmos. Ocean. Technol., 13, 967-986, 1996.

Bardouki, H., Liakakou, H., Economou, C., Smolik, J., Zdimal, V., Eleftheriadis, K., Lazaridis, M. and Mihalopoulos, N.: Chemical composition of size resolved atmospheric aerosols in the eastern Mediterranean during summer and winter, Atmos. Environ., 37, 195-208, 2003.

Bergin, M. H., Ogren, J. A., Schwartz, S. E., and McInnes, L. M.: Evaporation of ammonium nitrate aerosol in a heated nephelometer: implications for field measurements, Aerosol Sci. Technol., 31, 2878-2883, 1997.

Bergstrom, R. W., Russell, P. B., and Hignett, P.: Wavelength dependence of the absorption of black carbon particles: Predictions and results from the TARFOX experiment and implications for the aerosol single scattering albedo, J. Atmos. Sci., 59, 567-577, 2002.

Birmili, W., Stratmann, F., and Wiedensohler, A.: Design of a DMA-based size spectrometer for large particle size range and stable operation, J. Aerosol Sci., 30, 549-554, 1999.

Bohren, C. F. and Huffman, D. R.: Absorption and scattering of light by small particles, John Wiley \& Sons, Inc., 1998.

Bond, T. C. and Bergstrom, R. W.: Light absorption by carbonaceous particles: An investigative review, Aerosol Sci. Technol., 40, 27-67, 2006.

Bougiatioti, A., Fountoukis, C., Kalivitis, N., Pandis, S. N., Nenes, A., and Mihalopoulos, N.: Cloud condensation nuclei measurements in the marine boundary layer of the Eastern Mediter- ranean: $\mathrm{CCN}$ closure and droplet growth kinetics, Atmos. Chem. Phys., 9, 7053-7066, doi:10.5194/acp-9-7053-2009, 2009.

Brechtel, F. and Kreidenweis, S.: Predicting particle critical supersaturation from hygroscopic growth measurements in the humidified TDMA, part I: Theory and sensitivity studies, J. Atmos. Sci, 57, 1854-1871, 2000.

Bundke, U., Hänel, G., Horvath, H., Kaller, W., Seidl, S., Wex, H., Wiedensohler, A., Wiegner, M., and Freudenthaler, V.: Aerosol optical properties during the Lindenberg Aerosol Characterization Experiement (LACE-98), J. Geophys. Res., 107, 8123, doi:10.1029/2000JD000188, 2002.

Carrico, C. M., Rood, M. J., and Ogren, J. A.: Aerosol light scattering properties at Cape Grim, Tasmania, during the First Aerosol Characterization Experiment (ACE-1), J. Geophys. Res., 103, 16565-16574, 1998.

Carrico, C. M., Bergin, M. H., Xu, J., Baumann, K., and Maring, H.: Urban aerosol radiative properties: measurements during the 1999 Atlanta Supersite Experiment, J. Geophys. Res., 108, 8422, doi10.1029/2001JD001222, 2003.

Charlson, R. J., Langner, J., Rodhe, H., Leovy, C. B., and Warren, S. G.: Perturbation of the northern heimisphere radiative balance by backscattering from anthropogenic sulfate aerosols, Tellus, 43B, 152-163, 1991.

Cheng, Y. F., Eichler, H., Wiedensohler, A., Heintzenberg, H., Zhang, Y. H., Hu, M., Herrmann, H., Zeng, L. M., Liu, S., Gnauk, T., Brüggemann, E., and He, L. Y.: Mixing state of elemental carbon and non-light-absorbing aerosol components derived from in situ particle optical properties at Xinken in Pearl River Delta of China, J. Geophys. Res., 111, D20204, doi10.1029/2005JD006929, 2006.

Cheng, Y. F., Wiedensohler, A., Eichler, H., Heintzenberg, J., Tesche, M., Ansmann, A., Wendisch, M., Sua, H., Althausen, D., Herrmann, H., Gnauk, T., Brüggemann, E., Hub, M., and Zhang Y. H.: Relative humidity dependence of aerosol optical properties and direct radiative forcing in the surface boundary layer at Xinken in Pearl River Delta of China: An observation based numerical study, Atmos. Environ., 42, 6373-6397, 2008.

Chýlek, P. and Wong, J.: Effect of absorbing aerosols on global radiation buget, Geophys. Res. Lett., 22, 929-931, 1995.

Covert, D. S., Charlson, R. J., and Ahlquist, N. C.: A study of the relationship of chemcial compostion and humidity to light scattering by aerosols, J. Appl. Meteorol., 11, 968-976, 1972.

Dalzell, W.H. and Sarofim, A. F.: Optical constants of soot and their application to heat-flux calculations, J. Heat Transfer, 91, 100104, 1969.

DeCarlo, P., Slowik, J., Worsnop, D., Davidovits, P., and Jimenez, J.: Particle morphology and density characterization by combined mobility and aerodynamic diameter measurements. Part 1: theory, Aerosol Sci. Technol., 38, 1185-1205, 2004.

Engelhart, G. J., Hildebrandt, L., Kostenidou, E., Mihalopoulos, N., Donahue, N. M., and Pandis, S. N.: Water content of aged aerosol, Atmos. Chem. Phys., 11, 911-920, doi:10.5194/acp-11911-2011, 2011.

Fuller, K. A., Malm, W. C., and Kreidenweis, S. M.: Effects of mixing on extinction by carbonaceous particles, J. Geophys. Res., 104, 15941-15954, 1999.

Fuzzi, S., Andreae, M. O., Huebert, B. J., Kulmala, M., Bond, T. C., Boy, M., Doherty, S. J., Guenther, A., Kanakidou, M., Kawamura, K., Kerminen, V.-M., Lohmann, U., Russell, L. M., 
and Pöschl, U.: Critical assessment of the current state of scientific knowledge, terminology, and research needs concerning the role of organic aerosols in the atmosphere, climate, and global change, Atmos. Chem. Phys., 6, 2017-2038, doi:10.5194/acp-62017-2006, 2006.

Gassó, S., Hegg, D. A., Covert, D. S., Collins, D., Noone, K., Öström, E., Schmid, B., Russell, P. B., Livingston, J. M., Durkee, P. A., and Jonsson, H.: Influence of humidity on the aerosol scattering coefficient and its effct on the upwelling radiance during ACE-2, Tellus, 52B, 546-567, 2000.

Grant, K. E., Chuang, C. C., Grossman, A. S., and Penner, J. E.: Modeling the spectral optical properties of ammonium sulfate and biomass burning aerosols: Parameterization of relative humidity effects and model results, Atmos. Environ., 33, 26032620, 1999.

Guyon, P., Boucher, O., Graham B., Beck, J., Mayol-Bracero, O. L., Roberts, G. C., Maenhaut, W., Artaxo, P., and Andreae, M. O.: Refractive index of aerosol particles over the Amazon tropical forest during LBA-EUSTACH 1999, J. Aerosol Sci., 34, 883907, 2003.

Gysel, M., Weingartner, E., Nyeki, S., Paulsen, D., Baltensperger, U., Galambos, I., and Kiss, G.: Hygroscopic properties of water-soluble matter and humic-like organics in atmospheric fine aerosol, Atmos. Chem. Phys., 4, 35-50, doi:10.5194/acp-4-352004, 2004.

Gysel, M., Crosier, J., Topping, D. O., Whitehead, J. D., Bower, K. N., Cubison, M. J., Williams, P. I., Flynn, M. J., McFiggans, G. B., and Coe, H.: Closure study between chemical composition and hygroscopic growth of aerosol particles during TORCH2, Atmos. Chem. Phys., 7, 6131-6144, doi:10.5194/acp-7-61312007, 2007.

Hasan, H. and Dzubay, T. G.: Apportioning light extinction coefficients to chemical species in atmospheric aerosol, Atmos. Environ., 17, 1573-1581, 1983.

Haywood, J. and Boucher, O.: Estimates of the direct and indirect radiative forcing due to tropospheric aerosols: A review, Rev. Geophys., 38(4), 513-543, 2000.

Hegg, D.A., Covert, D.S., Rood, M.J., and Hobbs, P.V.: Measurements of aerosol optical properties in marine air, J. Geophys. Res., 101, 12 893-12 903, 1996.

Hegg, D.A., Covert, D.S., and Crahan, K.: The dependence of aerosol light scattering on RH over the Pacific Ocean, Geophys. Res. Lett., 29, 1219, doi10.1029/2001GL014495, 2002.

Heintzenberg, J. and Charlson, R.J.: Design and applications of the integrating nephelometer: A review, J. Atmos. Ocean. Technol., 13, 987-1000, 1996.

Heintzenberg, J., Wiedensohler, A., Tuch, T. M., Covert, D. S., Sheridan, P., Ogren, J. A., Gras, J., Nessler, R., Kleefeld, C., Kalivitis, N., Aaltonen, V., Wilhelm, R.-T., and Havlicek, M.: Intercomparisons and aerosol calibrations of 12 commercial integrating nephelometers of three manufacturers, J. Atmos. Ocean. Technol., 23, 902-914, 2006.

Hildebrandt, L., Engelhart, G. J., Mohr, C., Kostenidou, E., Lanz, V. A., Bougiatioti, A., DeCarlo, P. F., Prevot, A. S. H., Baltensperger, U., Mihalopoulos, N., Donahue, N. M., and Pandis, S. N.: Aged organic aerosol in the Eastern Mediterranean: the Finokalia Aerosol Measurement Experiment - 2008, Atmos. Chem. Phys., 10, 4167-4186, doi:10.5194/acp-10-4167-2010, 2010.
Im, J.-S., Saxena, V. K., and Wenny, B. N.: An assessment of hygroscopic growth factors for aerosols in the surface boundary layer for computing direct radiative forcing, J. Geophys. Res., 106, 20213-20224, 2001.

IPCC, Contribution of Working Group I to the Fourth Assessment Report of the Intergovernmental Panel on Climate Change, Solomon, S., Qin, D., Manning, M., Chen, Z., Marquis, M., Averyt, K. B., Tignor, M., and Miller, H. L., Cambridge University Press, Cambridge, UK, 2007.

Kanakidou, M., Seinfeld, J. H., Pandis, S. N., Barnes, I., Dentener, F. J., Facchini, M. C., Van Dingenen, R., Ervens, B., Nenes, A., Nielsen, C. J., Swietlicki, E., Putaud, J. P., Balkanski, Y., Fuzzi, S., Horth, J., Moortgat, G. K., Winterhalter, R., Myhre, C. E. L., Tsigaridis, K., Vignati, E., Stephanou, E. G., and Wilson, J.: Organic aerosol and global climate modelling: a review, Atmos. Chem. Phys., 5, 1053-1123, doi:10.5194/acp-5-1053-2005, 2005.

Kallos, G., Kotroni, V., Lagouvardos, K., and Papadopoulos, A.: On the long-range transport of air pollutants from Europe to Africa, Geophys. Res. Lett., 25, 619-622, 1998.

Kalivitis, N., Birmili, W., Stock, M., Wehner, B., Massling, A., Wiedensohler, A., Gerasopoulos, E., and Mihalopoulos, N.: Particle size distributions in the Eastern Mediterranean troposphere, Atmos. Chem. Phys., 8, 6729-6738, doi:10.5194/acp-8-67292008, 2008.

Koloutsou-Vakakis, S., Carrico, C. M., Kus, P., Rood, M. J., Li, Z., Shrestha, R., Ogren, J., Chow, J., and Watson, J.: Aerosol properties at a midlatitude Northern Hemisphere continental site, J. Geophys. Res., 106, 3019-3032, 2001.

Kotchenruther, R. A. and Hobbs, P. V.: Humidification factors of aerosols from biomass burning in Brazil, J. Geophys. Res., 103, 32081-32090, 1998.

Kotchenruther, R. A., Hobbs, P. V., and Hegg, D. A.: Humidification factors for atmospheric aerosols off the mid-Atlantic coast of the United States, J. Geophys. Res., 104, 2239-2251, 1999.

Kouvarakis, G., Bardouki, H., and Mihalopoulos, N., Sulfur budget above the eastern Mediterranean: Relative contribution of anthropogenic and biogenic sources, Tellus, 54B, 201-212, 2002.

Lee, S. C. and Tien, C. L.: Optical constants of soot in hydrocarbon flames, Symposium (Int.) on Combustion, Eighteenth Symposium (Int.) on Combustion, Vol. 18, Issue 1, 1159-1166, 1981.

Leinert, S. and Wiedensohler, A.: A DMA and APS based technique for measuring aerodynamic hygroscopic growth factors of micrometer-size aerosol particles, J. Aerosol Sci., 39, 393-402, 2008.

Lelieveld, J., Berresheim, H., Borrmann, S., Crutzen, P., Dentener, F., Fischer, H., Feichter, J., Flatau, P. J., Heland, J., Holzinger, R., Korrmann, R., Lawrence, M. G., Levin, Z., Markowicz, K. M., Mihalopoulos, N., Minikin, A., Ramanathan, V., de Reus, M., Roelofs, G. J., Scheeren, H. A., Sciare, J. , Schlager, H., Schultz, M., Siegmund, P. , Steil, B., Stephanou, E. G., Stier, P., Traub, M., Warneke, C., Williams, J., and Ziereis, H.: Global air pollution crossroads over the Mediterranean, Science, 298, 794799, 2002.

Levy, H. I.: Normal atmosphere: Large radical and formaldehyde concentrations predicted, Science, 173, 141-143, 1971.

Li-Jones, X., Maring, H. B., and Prospero, J. M.: Effect of relative humidity on light scattering by mineral dust aerosol as measured in the marine boundary layer over the tropical Atlantic Ocean, J. 
Geophys. Res., 103, 31113-31121, 1998.

Maenhaut, W., Hillamo, R., Mäkelä, T., Jafferzo, J.-L., Bergin, M., and Davidson, C.: A new cascade impactor for aerosol sampling with subsequent PIXE analysis, Nuclear Instruments and Methods in Physics Research Section B: Beam Interactions with Materials and Atoms, 109-110, Proceedings of the Seventh International Conference on Particle Induced X-ray Emission and Its Analytical Applications, 482-487, 1 April 1996.

Mallet, M., Pont, V., Liousse, C., Roger, J. C., and Dubuisson, P.: Simulation of aerosol radiative properties with the ORISAMRAD model during a pollution event (ESCOMPTE 2001), Atmos. Environ., 40, 7696-7705, 2006.

Malm, W. C., Sisler, J. F., Huffman, D., Eldred, R. A., and Gahill, T. A.: Spatial and seasonal trends in particle concentration and optical extinction in the United Sates, J. Geophys. Res., 99, 13471370, 1994.

Marshall, S. F., Covert, D. S., and Charlson, R. J.: Relationship between asymmetry parameter and hemispheric backscatter ratio: Implications for climate forcing by aerosols, Appl. Optics, 34, 6306-6311, 1995.

Maling, A., Wiedensohler, A., Busch, B., Neusüß, C., Quinn, P., Bates, T., and Covert, D.: Hygroscopic properties of different aerosol types over the Atlantic and Indian Oceans, Atmos. Chem. Phys., 3, 1377-1397, doi:10.5194/acp-3-1377-2003, 2003.

Massling, A., Stock, M., and Wiedensohler, W.: Diurnal, weekly, and seasonal variation of hygroscopic properties of submicrometer urban aerosol particles, Atmos. Environ., 39, 3911-3922, 2005.

Massoli, P., Lambe, A. T., Ahern, A. T., Williams, L. R., Ehn, M., Mikkilä, J., Canagaratna, M. R., Brune, W. H., Onasch, T. B., Jayne, J. T., Petäjä, T., Kulmala, M., Laaksonen, A., Kolb, C. E., Davidovits, P., and Worsnop, D. R.: Relationship between aerosol oxidation level and hygroscopic properties of laboratory generated secondary organic aerosol (SOA) particles, Geophys. Res. Lett., 37 , L24801, doi:10.1029/2010GL045258, 2010.

Meyer, N. K., Duplissy, J., Gysel, M., Metzger, A., Dommen, J., Weingartner, E., Alfarra, M. R., Prévôt, A. S. H., Fletcher, C., Good, N., McFiggans, G., Jonsson, Å. M., Hallquist, M., Baltensperger, U., and Ristovski, Z. D.: Analysis of the hygroscopic and volatile properties of ammonium sulphate seeded and unseeded SOA particles, Atmos. Chem. Phys., 9, 721-732, doi:10.5194/acp-9-721-2009, 2009.

Mihalopoulos, N., Stephanou, E., Kanakidou, M., Pilitsidis, S., and Bousquet, P.: Tropospheric aerosol ionic composition in the Eastern Mediterranean region, Tellus, 49B, 314-326, 1997.

Müller, T., Henzing, J. S., de Leeuw, G., Wiedensohler, A., Alastuey, A., Angelov, H., Bizjak, M., Collaud Coen, M., Engström, J. E., Gruening, C., Hillamo, R., Hoffer, A., Imre, K., Ivanow, P., Jennings, G., Sun, J. Y., Kalivitis, N., Karlsson, H., Komppula, M., Laj, P., Li, S.-M., Lunder, C., Marinoni, A., Martins dos Santos, S., Moerman, M., Nowak, A., Ogren, J. A., Petzold, A., Pichon, J. M., Rodriquez, S., Sharma, S., Sheridan, P. J., Teinilä, K., Tuch, T., Viana, M., Virkkula, A., Weingartner, E., Wilhelm, R., and Wang, Y. Q.: : Characterization and intercomparison of aerosol absorption photometers: result of two intercomparison workshops, Atmos. Meas. Tech., 4, 245-268, doi:10.5194/amt-4-245-2011, 2011.

Nessler, R., Weingartner, E., and Baltensperger, U.: Adaptation of dry nephelometer measurements to ambient conditions at the
Jungfraujoch, Environ. Sci. Technol., 39, 2219-2228, 2005.

Ogren, J. and Charlson, J.: Implications for models and measurements of chemical inhomogeneities among cloud droplets, Tellus, 44B, 489-504, 1992.

Petzold, A. and Schönlinner, M.: Multi-angle absorption photometry - a new method for the measurement of aerosol light absorption and atmospheric black carbon, Atmos. Environ., 35, 421441, 2004.

Pikridas, M., Bougiatioti, A., Hildebrandt, L., Engelhart, G. J., Kostenidou, E., Mohr, C., Prévôt, A. S. H., Kouvarakis, G., Zarmpas, P., Burkhart, J. F., Lee, B.-H., Psichoudaki, M., Mihalopoulos, N., Pilinis, C., Stohl, A., Baltensperger, U., Kulmala, M., and Pandis, S. N.: The Finokalia Aerosol Measurement Experiment - 2008 (FAME-08): an overview, Atmos. Chem. Phys., 10, 6793-6806, doi:10.5194/acp-10-6793-2010, 2010.

Press, W. H., Flannery, B. P., Teukolsky, S. A., and Wetterling, W. T.: Numerical recipes in Fortran, Cambridge Univ. Press, New York, USA, 2nd edn., 1992.

Randriamiarisoa, H., Chazette, P., Couvert, P., Sanak, J., and Mgie, G.: Relative humidity impact on aerosol parameters in a Paris suburban area, Atmos. Chem. Phys., 6, 1389-1407, doi:10.5194/acp-6-1389-2006, 2006.

Raut, J.-C. and Chazette, P.: Retrieval of aerosol complex refractive index from a synergy between lidar, sunphotometer and in situ measurements during LISAIR experiment, Atmos. Chem. Phys., 7, 2797-2815, doi:10.5194/acp-7-2797-2007, 2007.

Redemann, J., Russell, P. B., and Hamill, P.: Dependence of aerosol light absorption and single-scattering albedo on ambient relative humidity for sulfate aerosols with black carbon cores, J. Geophys. Res., 163(D21), 27485-27495, 2001.

Saxena, P. and Hildemann, L. M.: Water-soluble organics in atmospheric particles: A critical review of the literature and application of thermodynamics to identify candidate compounds. J. Atmos. Chem., 24, 57-109, 1996.

Sciare, J., Bardouki, H., Moulin, C., and Mihalopoulos, N.: Aerosol sources and their contribution to the chemical composition of aerosol in the Eastern Mediterranean Sea during summertime, Atmos. Chem. Phys., 3, 291-302, doi:10.5194/acp-3-291-2003, 2003.

Schkolnik, G., Chand, D., Hoffer, A., Andreae, M. O., Erlick, C., Swietlicki, E., and Rudich, Y.: Constraining the density and complex refractive index of elemental and organic carbon in biomass burning aerosol using optical and chemical measurements, Atmos. Environ., 41, 1107-1118, 2007.

Sheridan, P. J., Jefferson, A., and Ogren, J. A.: Spatial variability of submicrometer aerosol radiative properties over the Indian Ocean during INDOEX, J. Geophys. Res., 107, 8011, doi10.1029/2000JD000166, 2002.

Sloane, C. S.: Optical properties of aerosols-comparison of measurements with model calculations, Atmos. Environ., 17, 409416, 1983.

Sloane, C. S.: Optical properties of aerosols of mixed composition, Atmos. Environ., 18, 871-878, 1984.

Sloane, C. S. and Wolff, G. T.: Prediction of ambient light scattering using A physical model responsive to relative humidity: Validation with measurements from Detroit, 19, 669-680, 1985.

Sloane, C. S.: Effect of composition on aerosol light scattering efficiencies, Atmos. Environ., 20, 1025-1037, 1986.

Stokes, R. H. and Robinson, R. A.: Interactions in aqueous nonelec- 
trolyte solutions. I. Solute-solvent equilibria, J. Phys. Chem., 70, 2126-2130, 1966.

Swietlicki, E., Zhou, J., Berg, O., Martinsson, B., Frank, G. et al.: A closure study of sub-micrometer aerosol particle hygroscopic behavior, Atmos. Res., 50, 205-240, 1999.

Swietlicki, E., Hansson, H.-C., Hämeri, K., Svenningsson, B., Massling, A., McFiggans, G., McMurry, P. H., Petäjä, T., Tunved, P., Gysel, M., Topping, D., Weingartner, E., Baltensperger, U., Rissler, J., Wiedensohler, A., Kulmala, M.: Hygroscopic properties of submicrometer atmospheric aerosol particles measured with H-TDMA instruments in various environments - a review, Tellus, 60B, 432-469, 2008.

Svenningsson, B., Rissler, J., Swietlicki, E., Mircea, M., Bilde, M., Facchini, M. C., Decesari, S., Fuzzi, S., Zhou, J., Mønster, J., and Rosenørn, T.: : Hygroscopic growth and critical supersaturations for mixed aerosol particles of inorganics and organic compounds of atmospheric relevance, Atmos. Chem. Phys., 6, 1937-1952, doi:10.5194/acp-6-1937-2006, 2006.

Tang, I. N. and Munkelwitz, H. R.: Water activities, densities and refractive indices of aqueous sulfates and soldium nitrate droplets of atmospheric importance, J. Geophys. Res., 99, 18801-18808, 1994.

Tang, I. N.: Chemical and size effects of hygroscopic aerosols on light scatterring coeffcients, J. Geophys. Res., 101, 1924519250, 1996.

Teinilä, K., Kerminen, V.-M., and Hillamo, R.: A study of size segregated aerosol chemistry in the Antarctic atmosphere, J. Geophys. Res., 105, 3893-3904, 2000.

Twomey, S.: Atmospheric aerosols, Elsevier, New York, USA, 320 p., 1977.
Vardavas, I. M. and Taylor, F. M.: Radiation and Climate, International Series of Monographs on Physics No. 138, Oxford University Press, 2007.

Van Dingenen, R., Putaud, J.-P., Martins-Dos Santos, S., and Raes, F.: Physical aerosol properties and their relation to air mass origin at Monte Cimone (Italy) during the first MINATROC campaign, Atmos. Chem. Phys., 5, 2203-2226, doi:10.5194/acp-52203-2005, 2005.

Varutbangkul, V., Brechtel, F. J., Bahreini, R., Ng, N. L., Keywood, M. D., Kroll, J. H., Flagan, R. C., Seinfeld, J. H., Lee, A., and Goldstein, A. H.: Hygroscopicity of secondary organic aerosols formed by oxidation of cycloalkenes, monoterpenes, sesquiterpenes, and related compounds, Atmos. Chem. Phys., 6, 23672388, doi:10.5194/acp-6-2367-2006, 2006.

Wex, H., Neusüß, C., Wendisch, M., Stratmann, F., Koziar, C., Keil, A., Wiedensohler, A., and Ebert, M.: Particle scattering, backscattering, and absorption coefficients: An in situ closure and sensitivity study, J. Geophys. Res., 107(D21), 8122 doi:10.1029/2000JD000234, 2002.

Willeke, K. and Baron, P. A.: Aerosol measurement: Principles techniques and applications, Van Nostrand Reinhold, 115 Fifth Avenue, 10003 New York, USA, 1993.

Wiscombe, W. J. and Grams, G. W.: The backscattered fraction in two-stream approximations, J. Atmos. Sci., 33, 2440-2451, 1976.

Zdanovskii, A.: New methods for calculating solubilities of electrolytes in multicomponent systems, Zhur. Fiz. Khim, 22, 1475$1485,1948$. 